\title{
Encapsulation of Fruit Flavor Compounds through Interaction with Polysaccharides
}

\author{
Ivana Buljeta ${ }^{1}$, Anita Pichler ${ }^{1}$, Ivana Ivić ${ }^{1}$, Josip Šimunović ${ }^{2}$ and Mirela Kopjar ${ }^{1, * \mathbb{C}}$ \\ 1 Faculty of Food Technology Osijek, Josip Juraj Strossmayer University of Osijek, F. Kuhača 18, 31000 Osijek, \\ Croatia; ivana.buljeta@ptfos.hr (I.B.); anita.pichler@ptfos.hr (A.P.); ivana.ivic@ptfos.hr (I.I.) \\ 2 Department of Food, Bioprocessing and Nutrition Sciences, North Carolina State University, \\ Raleigh, NC 27695, USA; simun@ncsu.edu \\ * Correspondence: mirela.kopjar@ptfos.hr
}

check for

updates

Citation: Buljeta, I.; Pichler, A.; Ivić, I.; Šimunović, J.; Kopjar, M.

Encapsulation of Fruit Flavor

Compounds through Interaction with Polysaccharides. Molecules 2021, 26, 4207. https://doi.org/10.3390/ molecules26144207

Academic Editor: Cédric Delattre

Received: 7 June 2021

Accepted: 9 July 2021

Published: 11 July 2021

Publisher's Note: MDPI stays neutral with regard to jurisdictional claims in published maps and institutional affiliations.

Copyright: (c) 2021 by the authors Licensee MDPI, Basel, Switzerland. This article is an open access article distributed under the terms and conditions of the Creative Commons Attribution (CC BY) license (https:/ / creativecommons.org/licenses/by/ $4.0 /)$.

\begin{abstract}
Production and storage, the influence of packaging materials and the presence of other ingredients in fruit products can cause changes in flavor compounds or even their loss. Due to these issues, there is a need to encapsulate flavor compounds, and polysaccharides are often used as efficient carriers. In order to achieve effective encapsulation, satisfactory retention and/or controlled release of flavor compounds, it is necessary to understand the nature of the coated and coating materials. Interactions that occur between these compounds are mostly non-covalent interactions (hydrogen bonds, hydrophobic interactions and van der Waals forces); additionally, the formation of the inclusion complexes of flavor compounds and polysaccharides can also occur. This review provides insight into studies about the encapsulation of flavor compounds, as well as basic characteristics of encapsulation such as the choice of coating material, the effect of various factors on the encapsulation efficiency and an explanation of the nature of binding.
\end{abstract}

Keywords: polysaccharides; flavor compounds; encapsulation; interactions

\section{Introduction}

In order for food products to be accepted by consumers, they must, among other requirements, satisfy the organoleptic properties, which are mainly affected by flavor. The flavor compounds must pass from the product to the gas phase via the interface and reach the olfactory epithelium to be perceived during product consumption. The presence of other components (proteins, polysaccharides, lipids) in the product matrix strongly affects the retention and perception of flavor [1].

Flavor compounds are usually organic compounds [2] and include acids, alcohols, ketones, aldehydes, esters, neutral compounds, nitrogen and sulfur compounds and hydrocarbons [3]. These compounds have a low molecular weight $(<400 \mathrm{Da})$, are very sensitive to heat, light and oxygen, have a low boiling point and are highly volatile [4]. Table 1 shows some of the main physicochemical characteristics of flavor compounds that belong to the different chemical classes, as well as fruit sources and flavor descriptors for these compounds. 
Table 1. Physicochemical parameters, fruit source and descriptors of flavor compounds (adapted from [5-9]).

\begin{tabular}{|c|c|c|c|c|c|c|}
\hline Flavor Compounds & Formula & MW (g/mol) & $\log P(o / w)$ & VP & Fruit Source & Flavor Descriptors \\
\hline \multicolumn{7}{|l|}{ Acids } \\
\hline Acetic acid & $\mathrm{C}_{2} \mathrm{H}_{4} \mathrm{O}_{2}$ & 60.05 & -0.170 & 15.700 & Grape, blueberry, pineapple & Vinegar, sour \\
\hline 2-Methylbutanoic acid & $\mathrm{C}_{5} \mathrm{H}_{10} \mathrm{O}_{2}$ & 102.13 & 1.180 & 0.554 & Bilberry, blueberry, cranberry, wild strawberry & Fruity, cheesy \\
\hline 3-Methylbutanoic acid & $\mathrm{C}_{5} \mathrm{H}_{10} \mathrm{O}_{2}$ & 102.13 & 1.160 & 0.554 & $\begin{array}{l}\text { Apple, banana, blackberry, sour cherry, citrus fruits, } \\
\text { currant, grape, papaya, peach, pear, red raspberry }\end{array}$ & Cheesy \\
\hline Hexanoic acid & $\mathrm{C}_{6} \mathrm{H}_{12} \mathrm{O}_{2}$ & 116.16 & 1.920 & 0.158 & Overripe guava fruits, strawberry, noni fruit & Rancid, sour, cheesy \\
\hline Octanoic acid & $\mathrm{C}_{8} \mathrm{H}_{16} \mathrm{O}_{2}$ & 144.21 & 3.050 & 0.022 & Raw earth-almond, noni fruit & Sour, cheesy, rancid, fatty \\
\hline Decanoic acid & $\mathrm{C}_{10} \mathrm{H}_{20} \mathrm{O}_{2}$ & 172.27 & 4.090 & 15.000 & $\begin{array}{l}\text { Apple, banana, cherry, grape, orange, papaya, peach, } \\
\text { pear }\end{array}$ & Rancid, soapy \\
\hline \multicolumn{7}{|l|}{ Alcohols } \\
\hline Ethanol & $\mathrm{C}_{6} \mathrm{H}_{6} \mathrm{O}$ & 46.07 & -0.190 & 44.600 & Orange, mandarin, tangerine & Alcoholic \\
\hline 2-Butanol & $\mathrm{C}_{4} \mathrm{H}_{10} \mathrm{O}$ & 74.12 & 0.610 & 18.300 & Apple, pear & Alcoholic \\
\hline 2-Methyl-1-propanol & $\mathrm{C}_{4} \mathrm{H}_{10} \mathrm{O}$ & 74.12 & 0.760 & 9.000 & Apple, currant, apricot, banana, sweet cherry & Alcoholic, nail polish \\
\hline 1-Butanol & $\mathrm{C}_{4} \mathrm{H}_{10} \mathrm{O}$ & 74.12 & 0.880 & 6.700 & Apple, mulberry & Alcoholic \\
\hline 2-Methyl-3-buten-2-ol & $\mathrm{C}_{5} \mathrm{H}_{10} \mathrm{O}$ & 86.13 & 0.892 & 22.939 & Bilberry, cherimoya, cranberry, black currant, mango & Herbaceous \\
\hline 1-Penten-3-ol & $\mathrm{C}_{5} \mathrm{H}_{10} \mathrm{O}$ & 86.13 & 0.991 & 11.179 & Banana, blueberry, black currant & Green \\
\hline 3-Methyl-3-buten-1-ol & $\mathrm{C}_{5} \mathrm{H}_{10} \mathrm{O}$ & 86.13 & 1.098 & 10.245 & Barbados cherry, apple, blackberry, boysenberry & Herbaceous \\
\hline 2-Methyl-1-butanol & $\mathrm{C}_{5} \mathrm{H}_{12} \mathrm{O}$ & 88.15 & 1.290 & 4.760 & Bilberry, plum & Alcoholic, ripe fruit, burnt \\
\hline 3-Methyl-1-butanol & $\mathrm{C}_{5} \mathrm{H}_{12} \mathrm{O}$ & 88.15 & 1.160 & 2.370 & Apple, banana, blackberry, & Whiskey, malt \\
\hline 2-Pentanol & $\mathrm{C}_{5} \mathrm{H}_{12} \mathrm{O}$ & 88.15 & 1.190 & 8.047 & Apple, banana, black currant, grape, papaya & Green, fuel oil \\
\hline cis-3-Hexen-1-ol & $\mathrm{C}_{6} \mathrm{H}_{12} \mathrm{O}$ & 100.16 & 1.697 & 1.039 & Apple & Green, leafy \\
\hline trans-2-Hexen-1-ol & $\mathrm{C}_{6} \mathrm{H}_{12} \mathrm{O}$ & 100.16 & 1.655 & 0.873 & Black currant, apple, grapefruit, kiwi & Green, leafy \\
\hline
\end{tabular}


Table 1. Cont.

\begin{tabular}{|c|c|c|c|c|c|c|}
\hline Flavor Compounds & Formula & MW (g/mol) & $\log P(o / w)$ & VP & Fruit Source & Flavor Descriptors \\
\hline cis-2-Hexen-1-ol & $\mathrm{C}_{6} \mathrm{H}_{12} \mathrm{O}$ & 100.16 & 1.755 & 0.873 & $\begin{array}{l}\text { Sour cherry, black currant, blueberry, apple, kiwi, } \\
\text { papaya, quince }\end{array}$ & Green \\
\hline 1-Hexanol & $\mathrm{C}_{6} \mathrm{H}_{16} \mathrm{O}$ & 102.18 & 2.030 & 0.947 & $\begin{array}{c}\text { Bilberry, apple, black currant, grapefruit, guava, } \\
\text { orange, papaya, plum }\end{array}$ & $\begin{array}{l}\text { Sweet, alcoholic, fresh-cut } \\
\text { grass }\end{array}$ \\
\hline Benzyl alcohol & $\mathrm{C}_{7} \mathrm{H}_{8} \mathrm{O}$ & 108.14 & 1.100 & 0.094 & $\begin{array}{l}\text { Apricot, apple, bilberry, blueberry, cranberry, fig, } \\
\text { mandarin, papaya, plum, }\end{array}$ & Floral, sweet, cherry \\
\hline 1-Heptanol & $\mathrm{C}_{7} \mathrm{H}_{16} \mathrm{O}$ & 116.20 & 2.367 & 0.325 & Strawberry, plum, apricot & Fatty, green, pungent \\
\hline 2-Heptanol & $\mathrm{C}_{7} \mathrm{H}_{16} \mathrm{O}$ & 116.20 & 2.310 & 0.886 & Clove fruit, banana, coconut & Fruity, herbaceous, musty \\
\hline Phenylethyl alcohol & $\mathrm{C}_{8} \mathrm{H}_{10} \mathrm{O}$ & 122.17 & 1.360 & 0.087 & $\begin{array}{l}\text { Black walnut, strawberry, red raspberry, plum, pear, } \\
\text { orange, lemon, blueberry, banana, apricot }\end{array}$ & Floral, rose-like, honey \\
\hline 6-Methyl-5-hepten-2-ol & $\mathrm{C}_{8} \mathrm{H}_{16} \mathrm{O}$ & 128.21 & 2.570 & 0.362 & Citrus fruits & Green \\
\hline 1-Octen-3-ol & $\mathrm{C}_{8} \mathrm{H}_{16} \mathrm{O}$ & 128.21 & 2.519 & 0.531 & Banana, black currant, strawberry, & Mushroom \\
\hline 1-Octanol & $\mathrm{C}_{8} \mathrm{H}_{18} \mathrm{O}$ & 130.23 & 3.0 & 0.079 & Grapefruit, guava, lime, mandarin, orange, plum & Sweet, rose-like \\
\hline Cinnamyl alcohol & $\mathrm{C}_{9} \mathrm{H}_{10} \mathrm{O}$ & 134.18 & 1.950 & 0.012 & Fig, red raspberry & Floral \\
\hline 2-Nonanol & $\mathrm{C}_{9} \mathrm{H}_{20} \mathrm{O}$ & 144.26 & 3.230 & 0.108 & Apple, citrus fruits, strawberry, banana & Fruity, green \\
\hline 4-Phenyl-2-butanol & $\mathrm{C}_{10} \mathrm{H}_{14} \mathrm{O}$ & 150.22 & 2.131 & 0.015 & Blackberry & Floral \\
\hline 1-Decanol & $\mathrm{C}_{10} \mathrm{H}_{22} \mathrm{O}$ & 158.28 & 4.570 & 0.009 & Apple, lime, mandarin, pear & Fruity, floral, fatty \\
\hline 2-Undecanol & $\mathrm{C}_{11} \mathrm{H}_{24} \mathrm{O}$ & 172.31 & 4.249 & 0.015 & Banana, apple, papaya, strawberry & Fruity \\
\hline \multicolumn{7}{|l|}{ Aldehydes } \\
\hline Acetaldehyde & $\mathrm{C}_{2} \mathrm{H}_{4} \mathrm{O}$ & 44.05 & -0.340 & 902.000 & $\begin{array}{l}\text { Apple, date palm, fig, guava, mandarin, olive, plum, } \\
\text { red raspberry, strawberry }\end{array}$ & Pungent, overripe, apple \\
\hline 2-Methylbutanal & $\mathrm{C}_{5} \mathrm{H}_{10} \mathrm{O}$ & 86.13 & 1.267 & 49.317 & Cayenne, grapefruit, apple, papaya, plum & Green, malty \\
\hline 3-Methylbutanal & $\mathrm{C}_{5} \mathrm{H}_{10} \mathrm{O}$ & 86.13 & 1.267 & 49.317 & Plum, banana, apple & Fresh grass, cocoa \\
\hline Furfural & $\mathrm{C}_{5} \mathrm{H}_{4} \mathrm{O}_{2}$ & 96.09 & 0.410 & 2.234 & $\begin{array}{l}\text { Red raspberry, plum, orange, lime, guava, grapefruit, } \\
\text { cranberry, apricot, apple }\end{array}$ & Almond, bread \\
\hline
\end{tabular}


Table 1. Cont.

\begin{tabular}{|c|c|c|c|c|c|c|}
\hline Flavor Compounds & Formula & MW (g/mol) & $\log P(o / w)$ & VP & Fruit Source & Flavor Descriptors \\
\hline 2-Hexenal & $\mathrm{C}_{6} \mathrm{H}_{10} \mathrm{O}$ & 98.14 & 1.790 & 4.624 & $\begin{array}{c}\text { Avocado, banana, apricot, apple, bilberry, blueberry, } \\
\text { currant, peach, plum }\end{array}$ & Green, leaf \\
\hline Hexanal & $\mathrm{C}_{6} \mathrm{H}_{12} \mathrm{O}$ & 100.16 & 1.780 & 10.888 & $\begin{array}{c}\text { Cranberry, guava, orange, papaya, apple, banana, } \\
\text { plum, watermelon }\end{array}$ & Green, unripe fruit, grassy \\
\hline Benzaldehyde & $\mathrm{C}_{7} \mathrm{H}_{6} \mathrm{O}$ & 106.12 & 1.480 & 1.270 & $\begin{array}{l}\text { Bitter almond, apple, sour cherry, fig, guava, lemon, } \\
\text { lime, mandarin, orange, peach, plum, red raspberry }\end{array}$ & Almond, burnt sugar \\
\hline 5-Methyl-2-furfural & $\mathrm{C}_{6} \mathrm{H}_{6} \mathrm{O}_{2}$ & 110.11 & 0.670 & 0.644 & $\begin{array}{l}\text { Blackberry, cloudberry, cranberry, mango, red } \\
\text { raspberry }\end{array}$ & Almond, caramel \\
\hline $\begin{array}{c}\text { trans, } \\
\text { trans-2,4-Heptadienal }\end{array}$ & $\mathrm{C}_{7} \mathrm{H}_{10} \mathrm{O}$ & 110.16 & 1.891 & 1.044 & Cranberry, bilberry, plum & Fatty, green \\
\hline Heptanal & $\mathrm{C}_{7} \mathrm{H}_{14} \mathrm{O}$ & 114.19 & 2.442 & 3.854 & Orange, strawberry, plum, papaya, guava & Fatty, pungent \\
\hline $\begin{array}{c}5- \\
\text { (Hydroxymethyl)furfural }\end{array}$ & $\mathrm{C}_{6} \mathrm{H}_{6} \mathrm{O}_{3}$ & 126.11 & -0.778 & 0.001 & Pineapple, cloudberry, roasted almond & Floral \\
\hline Octanal & $\mathrm{C}_{8} \mathrm{H}_{16} \mathrm{O}$ & 128.21 & 2.951 & 2.068 & $\begin{array}{c}\text { Guava, lime, mandarin, orange, papaya, plum, } \\
\text { tangerine, lemon }\end{array}$ & Lemon, soap \\
\hline \multicolumn{7}{|l|}{ Ketones } \\
\hline 2-Butanone & $\mathrm{C}_{4} \mathrm{H}_{8} \mathrm{O}$ & 72.11 & 0.290 & 90.600 & Black currant, plum, apple, guava & Floral, vegetable \\
\hline 2-Pentanone & $\mathrm{C}_{5} \mathrm{H}_{10} \mathrm{O}$ & 86.13 & 0.910 & 38.577 & Banana, apple, pineapple & Fruity \\
\hline Acetoin & $\mathrm{C}_{4} \mathrm{H}_{8} \mathrm{O}_{2}$ & 88.11 & -0.360 & 2.690 & Currant, fig, apple, plum, red raspberry & Buttery \\
\hline 2-Heptanone & $\mathrm{C}_{7} \mathrm{H}_{14} \mathrm{O}$ & 114.19 & 1.980 & 4.732 & Sour cherry, papaya, pear, berries & Fruity \\
\hline Furaneol & $\mathrm{C}_{6} \mathrm{H}_{8} \mathrm{O}_{3}$ & 128.13 & -0.076 & 0.032 & $\begin{array}{l}\text { Strawberry, roasted almond, guava, grapefruit, } \\
\text { mango, pineapple, red raspberry }\end{array}$ & Strawberry, sweet, caramel \\
\hline 2-Octanone & $\mathrm{C}_{8} \mathrm{H}_{16} \mathrm{O}$ & 128.21 & 2.370 & 1.725 & Clove fruit, banana & $\begin{array}{l}\text { Soap, gasoline, cheesy, fatty } \\
\text { green }\end{array}$ \\
\hline 2-Nonanone & $\mathrm{C}_{9} \mathrm{H}_{18} \mathrm{O}$ & 142.24 & 3.140 & 0.645 & Clove fruit, strawberry & Fruity, green \\
\hline 2-Undecanone & $\mathrm{C}_{11} \mathrm{H}_{22} \mathrm{O}$ & 170.30 & 4.090 & 0.098 & Banana, guava, strawberry & Fruity \\
\hline
\end{tabular}


Table 1. Cont.

\begin{tabular}{|c|c|c|c|c|c|c|}
\hline Flavor Compounds & Formula & MW (g/mol) & $\log P(o / w)$ & VP & Fruit Source & Flavor Descriptors \\
\hline$\beta$-Damascenone & $\mathrm{C}_{13} \mathrm{H}_{18} \mathrm{O}$ & 190.29 & 4.042 & 0.020 & Strawberry, red raspberry, black currant, apricot & Sweet, fruity, apple \\
\hline$\alpha$-Ionone & $\mathrm{C}_{13} \mathrm{H}_{20} \mathrm{O}$ & 192.30 & 3.995 & 0.014 & $\begin{array}{c}\text { Blackberry, roasted almond, black currant, plum, red } \\
\text { raspberry }\end{array}$ & Berry, woody \\
\hline$\beta$-Ionone & $\mathrm{C}_{13} \mathrm{H}_{20} \mathrm{O}$ & 192.30 & 3.995 & 0.017 & $\begin{array}{l}\text { Roasted almond, grape, guava, papaya, peach, red } \\
\text { raspberry, watermelon }\end{array}$ & Fruity, woody \\
\hline \multicolumn{7}{|c|}{ Terpenes and terpenoids } \\
\hline$\beta$-Pinene & $\mathrm{C}_{10} \mathrm{H}_{16}$ & 136.24 & 4.160 & 2.930 & Black currant, guava, lime, mandarin, orange, plum & Woody, resinous \\
\hline Camphene & $\mathrm{C}_{10} \mathrm{H}_{16}$ & 136.24 & 4.350 & 3.000 & Black currant, lime, mandarin, orange & Woody \\
\hline$\alpha$-Phellandrene & $\mathrm{C}_{10} \mathrm{H}_{16}$ & 136.24 & 4.408 & 1.856 & Lime, mandarin, orange, papaya & Sweet \\
\hline Limonene & $\mathrm{C}_{10} \mathrm{H}_{16}$ & 136.24 & 4.570 & 1.550 & $\begin{array}{l}\text { Blueberry, coconut, guava, lemon, lime, mandarin, } \\
\text { orange, plum }\end{array}$ & Citrus, minty \\
\hline Sabinene & $\mathrm{C}_{10} \mathrm{H}_{16}$ & 136.24 & 3.940 & 2.633 & $\begin{array}{c}\text { Red raspberry, orange, mandarin, lime, lemon, } \\
\text { grapefruit }\end{array}$ & Woody \\
\hline$\gamma$-Terpinene & $\mathrm{C}_{10} \mathrm{H}_{16}$ & 136.24 & 4.500 & 1.075 & Grapefruit, lemon, lime, mandarin, orange, papaya & Fruity, lemon-like \\
\hline p-Cymene & $\mathrm{C}_{10} \mathrm{H}_{14}$ & 134.22 & 4.100 & 1.460 & $\begin{array}{l}\text { Apricot, blackberry, black currant, guava, mandarin, } \\
\text { pineapple }\end{array}$ & Carrot-like \\
\hline$\alpha$-Terpinolene & $\mathrm{C}_{10} \mathrm{H}_{16}$ & 136.24 & 4.470 & 1.126 & $\begin{array}{l}\text { Apricot, blueberry, cherry, coconut, black currant, } \\
\text { lemon, lime, mandarin, orange, peach, pineapple, } \\
\text { red raspberry }\end{array}$ & Sweet, piney \\
\hline Myrcene & $\mathrm{C}_{10} \mathrm{H}_{16}$ & 136.24 & 4.170 & 2.290 & $\begin{array}{c}\text { Blueberry, black currant, guava, lime, mandarin, } \\
\text { orange, papaya }\end{array}$ & Balsamic \\
\hline p-Cymen-8-ol & $\mathrm{C}_{10} \mathrm{H}_{14} \mathrm{O}$ & 150.22 & 2.251 & 0.020 & Bilberry, currant & Musty \\
\hline Carvone & $\mathrm{C}_{10} \mathrm{H}_{14} \mathrm{O}$ & 150.22 & 3.070 & 0.160 & Mandarin, orange, plum & Minty \\
\hline Myrtenal & $\mathrm{C}_{10} \mathrm{H}_{14} \mathrm{O}$ & 150.22 & 2.980 & 0.145 & Black pepper fruit & Spicy, cinnamon \\
\hline Myrtenol & $\mathrm{C}_{10} \mathrm{H}_{16} \mathrm{O}$ & 152.24 & 3.220 & 0.018 & Bilberry, cranberry, red raspberry, wild strawberry & $\begin{array}{l}\text { Flowery, minty, medicinal, } \\
\text { woody }\end{array}$ \\
\hline
\end{tabular}


Table 1. Cont.

\begin{tabular}{|c|c|c|c|c|c|c|}
\hline Flavor Compounds & Formula & MW (g/mol) & $\log P(o / w)$ & VP & Fruit Source & Flavor Descriptors \\
\hline Camphor & $\mathrm{C}_{10} \mathrm{H}_{16} \mathrm{O}$ & 152.24 & 2.380 & 0.650 & Coriander fruit & Medicinal, woody \\
\hline 1-Terpineol & $\mathrm{C}_{10} \mathrm{H}_{18} \mathrm{O}$ & 154.25 & 2.538 & 0.032 & $\begin{array}{l}\text { Apple, blueberry, cherry, coconut, cranberry, black } \\
\text { currant, guava, lime, mandarin, orange, papaya, } \\
\text { peach, pineapple, plum }\end{array}$ & Woody, musty \\
\hline cis-Rose oxide & $\mathrm{C}_{10} \mathrm{H}_{18} \mathrm{O}$ & 154.25 & 3.126 & 0.551 & Lychee & Floral, green \\
\hline 4-Terpineol & $\mathrm{C}_{10} \mathrm{H}_{18} \mathrm{O}$ & 154.25 & 3.260 & 0.048 & $\begin{array}{l}\text { Apple, sour cherry, black currant, lime, mandarin, } \\
\text { orange, papaya, pineapple, plum }\end{array}$ & Spicy \\
\hline Linalool & $\mathrm{C}_{10} \mathrm{H}_{18} \mathrm{O}$ & 154.25 & 2.970 & 0.016 & $\begin{array}{l}\text { Apricot, blueberry, sour cherry, cranberry, fig, grape, } \\
\text { lime, nectarine, orange, papaya, pineapple, plum }\end{array}$ & $\begin{array}{l}\text { Floral, rosy, green, fruity, } \\
\text { citrus }\end{array}$ \\
\hline$\alpha$-Terpineol & $\mathrm{C}_{10} \mathrm{H}_{18} \mathrm{O}$ & 154.25 & 2.670 & 0.028 & $\begin{array}{l}\text { Apple, apricot, blueberry, cherry, coconut, black } \\
\text { currant, guava, lemon, lime, mandarin, orange, } \\
\text { papaya, peach, pineapple, plum, red raspberry }\end{array}$ & Floral, green, fruity \\
\hline Nerol & $\mathrm{C}_{10} \mathrm{H}_{18} \mathrm{O}$ & 154.25 & 3.470 & 0.013 & $\begin{array}{l}\text { Blueberry, currant, lemon, lime, mandarin, orange, } \\
\text { plum }\end{array}$ & Orange flowers, rose \\
\hline Geraniol & $\mathrm{C}_{10} \mathrm{H}_{18} \mathrm{O}$ & 154.25 & 3.560 & 0.021 & $\begin{array}{l}\text { Apricot, blackberry, blueberry, boysenberry, grape, } \\
\text { lemon, mandarin, orange, plum, red raspberry }\end{array}$ & Roses, geranium \\
\hline Citronellol & $\mathrm{C}_{10} \mathrm{H}_{20} \mathrm{O}$ & 156.27 & 3.300 & 0.020 & $\begin{array}{c}\text { Apricot, apple, blueberry, lychee, mandarin, mango, } \\
\text { orange }\end{array}$ & Sweet, floral, rose, citrus \\
\hline Linalool oxide & $\mathrm{C}_{10} \mathrm{H}_{18} \mathrm{O}_{2}$ & 170.25 & 1.375 & 0.002 & $\begin{array}{l}\text { Currant, grape, apple, apricot, blackberry, } \\
\text { cloudberry, lychee, papaya, pineapple, red raspberry }\end{array}$ & Woody, floral \\
\hline Theaspirane & $\mathrm{C}_{13} \mathrm{H}_{22} \mathrm{O}$ & 194.32 & 4.204 & 0.028 & Blackberry, grape, guava & Fruity \\
\hline trans, trans- $\alpha$-Farnesene & $\mathrm{C}_{15} \mathrm{H}_{24}$ & 204.36 & 6.139 & 0.010 & Apple, grape, guava, lime, mandarin, orange, pear & Sweet, flowery \\
\hline \multicolumn{7}{|l|}{ Esters } \\
\hline Ethyl acetate & $\mathrm{C}_{4} \mathrm{H}_{8} \mathrm{O}_{2}$ & 88.11 & 0.730 & 111.716 & $\begin{array}{l}\text { Pineapple, apple, fig, guava, black currant, papaya, } \\
\text { peach, red raspberry }\end{array}$ & Fruity, floral, pineapple \\
\hline Ethyl butyrate & $\mathrm{C}_{6} \mathrm{H}_{12} \mathrm{O}_{2}$ & 116.16 & 1.804 & 12.800 & $\begin{array}{c}\text { Grapefruit, guava, fig, kiwi, mango, papaya, } \\
\text { pineapple, plum, wild strawberry, banana, apple }\end{array}$ & $\begin{array}{l}\text { Fruity, sweet, pineapple, } \\
\text { apple }\end{array}$ \\
\hline Butyl acetate & $\mathrm{C}_{6} \mathrm{H}_{12} \mathrm{O}_{2}$ & 116.16 & 1.780 & 11.500 & $\begin{array}{l}\text { Apple, banana, cherry, black currant, grape, guava, } \\
\text { pear, plum, peach, red raspberry, wild strawberry }\end{array}$ & Fruity, apple, pineapple \\
\hline
\end{tabular}


Table 1. Cont.

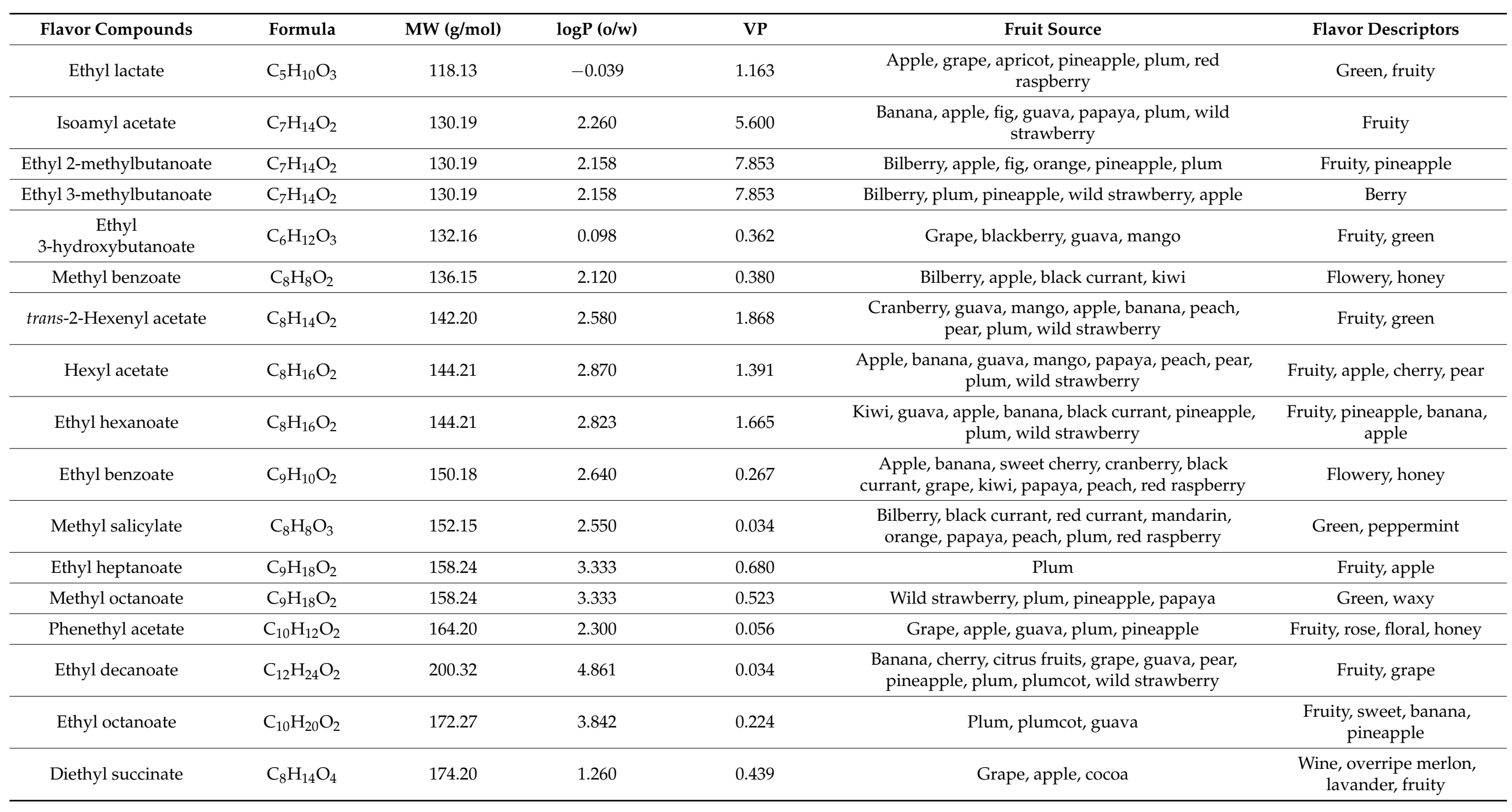


Table 1. Cont.

\begin{tabular}{|c|c|c|c|c|c|c|}
\hline Flavor Compounds & Formula & MW (g/mol) & $\log P(o / w)$ & VP & Fruit Source & Flavor Descriptors \\
\hline Ethyl cinnamate & $\mathrm{C}_{11} \mathrm{H}_{12} \mathrm{O}_{2}$ & 176.22 & 2.990 & 0.003 & Currant, guava, peach, wild strawberry & Fruity, honey, cinnamon \\
\hline $\begin{array}{l}\text { Ethyl } \\
\text { 3-phenylpropanoate }\end{array}$ & $\mathrm{C}_{11} \mathrm{H}_{14} \mathrm{O}_{2}$ & 178.23 & 2.730 & 0.028 & Muskmelon & Floral \\
\hline Ethyl laurate & $\mathrm{C}_{14} \mathrm{H}_{28} \mathrm{O}_{2}$ & 228.38 & 5.710 & 0.007 & Grape, guava, pear, wild strawberry & Waxy, fruity, floral, leaf \\
\hline Ethyl hexadecanoate & $\mathrm{C}_{18} \mathrm{H}_{36} \mathrm{O}_{2}$ & 284.48 & 7.918 & 0.000 & Apricot, guava, & Waxy \\
\hline \multicolumn{7}{|l|}{ Phenols } \\
\hline 4-Ethylphenol & $\mathrm{C}_{8} \mathrm{H}_{10} \mathrm{O}$ & 122.17 & 2.580 & 0.083 & Cranberry & Smoky \\
\hline 4-Methylguaiacol & $\mathrm{C}_{8} \mathrm{H}_{10} \mathrm{O}_{2}$ & 138.17 & 1.925 & 0.078 & Cocoa & Spicy, smoky \\
\hline 4-Vinylguaiacol & $\mathrm{C}_{9} \mathrm{H}_{10} \mathrm{O}_{2}$ & 150.18 & 2.573 & 0.019 & Apple, wild strawberry & Woody, smoky \\
\hline Vanillin & $\mathrm{C}_{8} \mathrm{H}_{8} \mathrm{O}_{3}$ & 152.15 & 1.210 & 0.002 & $\begin{array}{l}\text { Blueberry, clove fruit, grape, pineapple, wild } \\
\text { strawberry }\end{array}$ & Sweet, creamy, vanilla \\
\hline Eugenol & $\mathrm{C}_{10} \mathrm{H}_{12} \mathrm{O}_{2}$ & 164.20 & 2.270 & 0.010 & $\begin{array}{l}\text { Blueberry, clove fruit, cranberry, black currant, fig, } \\
\text { guava, peach, plum, red raspberry }\end{array}$ & Clove, spicy, pungent \\
\hline Elemicin & $\mathrm{C}_{12} \mathrm{H}_{16} \mathrm{O}_{3}$ & 208.26 & 2.298 & 0.007 & Nutmeg & Woody, floral \\
\hline \multicolumn{7}{|l|}{ Lactones } \\
\hline$\gamma$-Butyrolactone & $\mathrm{C}_{4} \mathrm{H}_{6} \mathrm{O}_{2}$ & 86.09 & -0.640 & 0.450 & Mango, pineapple & Creamy, caramel, sweet \\
\hline$\gamma$-Nonalactone & $\mathrm{C}_{9} \mathrm{H}_{16} \mathrm{O}_{2}$ & 156.22 & 1.942 & 0.009 & $\begin{array}{l}\text { Apricot, coconut, black currant, papaya, pineapple, } \\
\text { plum }\end{array}$ & Coconut \\
\hline
\end{tabular}

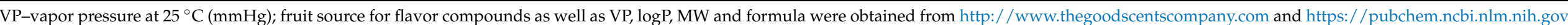
(accessed on 1 July 2021). 
Most of them have a desirable fragrance and are therefore often used in the food and chemical industries (e.g., beverage, bakery, cosmetics and perfumes industries) [10]. A limiting factor for the application of some of these compounds is their toxicity, and it is of great importance to present some safety information such as $\mathrm{LC}_{50}$ (median lethal dose) (Table 2). In addition, they may possess antibacterial, antioxidant and antifungal properties [11].

Production and storage, the influence of packaging materials and the presence of other ingredients in the products cause changes in the flavor compounds or even their loss. Since flavor is an important factor influencing the sale of a particular product and affects consumer satisfaction, there is a need to encapsulate it in order to preserve/partially preserve their native form and prevent the aforementioned problems [12-14]. Encapsulation is a technique in which a substance or a mixture of substances is coated or entrapped in another material that forms a protective shell or wall $[15,16]$. Polysaccharides, as ingredients usually present in foods, can be used as carriers of flavor compounds. They are known for their contribution to the reduction of flavor release because they increase viscosity and/or create molecular interactions with flavor compounds [17] and additionally possess different functional properties and possible health benefits. Starch, as the most important polysaccharide in the food industry, is used as a gelling agent, stabilizer and/or thickener and at the same time can interact with small molecules such as flavor compounds [18]. Dietary fibers are oligosaccharides, polysaccharides and derivatives resistant to digestion and adsorption in the human small intestine, and they can be completely or partially fermented in the large intestine [19-21]. They are classified into soluble and insoluble fibers. Soluble dietary fibers are pectins, $\beta$-glucans, oligosaccharides, gums, mucilage and inulin. Insoluble dietary fibers include cellulose, hemicellulose, chitin and resistant starch $[21,22]$. There are many positive health effects attributed to dietary fibers, such as reduced hypertension, hyperlipidemia, obesity, constipation and type II diabetes [23-25]. Additionally, foods enriched with dietary fibers had better properties (increased water retention capacity, gel formation, viscosity, fermentability or adsorption) [22].

The effect of polysaccharides on flavor is complex because they can have an effect on both the retention and release of the flavor. They can directly capture flavor compounds and thus retain them while at the same time they cause textural and physicochemical changes in the matrix and so alter the release of the flavor [5]. The rate of release of flavors from the product depends on flavor compounds volatility, which is a thermodynamic factor, but also on the resistance to mass transfer from the product to the air, which is a kinetic factor [26].

Increased retention of flavor compounds (from the same group) by polysaccharides was observed at higher molecular weight while increased volatility and polarity decreased retention. It is interesting to mention that the crystallization of the carrier led to reduced retention of the flavor compounds because of a cross-linking effect that was created and caused a reduction in the surface area between the polymer chains. In this way, flavor compounds were forcibly squeezed out from the matrix to the surface [27].

Non-aromatic compounds in foods (such as polysaccharides) can have a major impact on the overall flavor since they can affect the rate and extent of flavor release. The binding of flavor compounds can lead to an imbalance of the flavor profile, and it is necessary to know the mechanism of release of flavor components from the product matrices, especially when new products are developed. Additionally, it is important to know the nature of the interactions that occur between polysaccharides and flavor compounds, and this review will provide a better insight into this topic. 
Table 2. Median lethal dose $\left(\mathrm{LD}_{50}\right)$ of flavor compounds (FC).

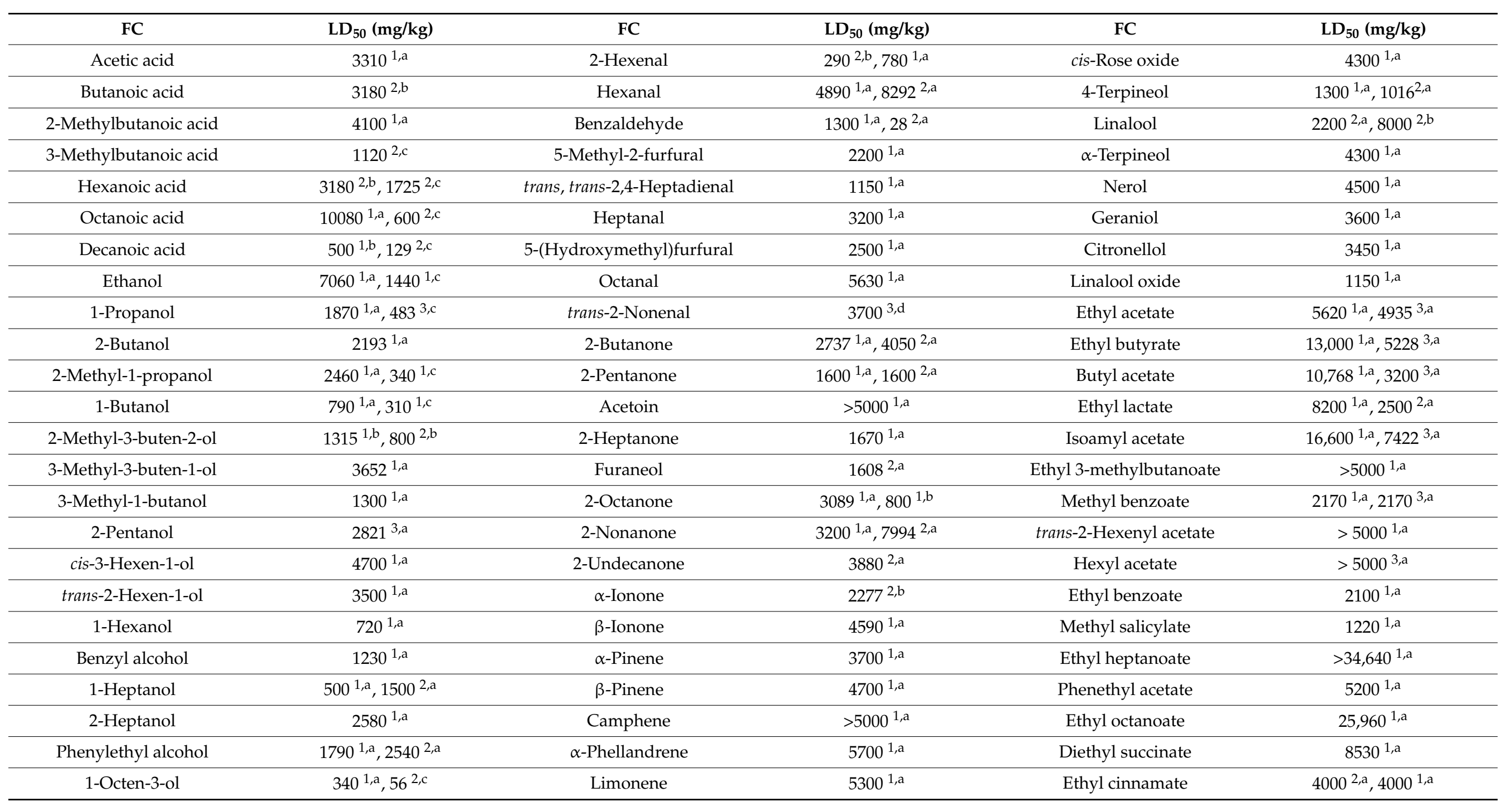


Table 2. Cont.

\begin{tabular}{|c|c|c|c|c|c|}
\hline FC & $\mathrm{LD}_{50}(\mathrm{mg} / \mathrm{kg})$ & FC & $\mathrm{LD}_{50}(\mathrm{mg} / \mathrm{kg})$ & FC & $\mathrm{LD}_{50}(\mathrm{mg} / \mathrm{kg})$ \\
\hline 1-Octanol & $1790^{2, a}, 69^{2, c}$ & $\gamma$-Terpinene & $3650^{1, a}$ & Phenol & $317^{1, a}, 270^{2, a}, 127^{1, b}$ \\
\hline Cinnamyl alcohol & $2675^{2, a}$ & p-Cymene & $4750^{1, a}$ & 4-Ethylphenol & $>5000^{1, \mathrm{a}}, 138^{2, \mathrm{~b}}$ \\
\hline 1-Decanol & $4720^{1, a}, 6500^{3}$ & Myrcene & $>5000^{1, a}$ & Vanillin & $475^{2, \mathrm{~b}}, 4370^{1, \mathrm{a}}$ \\
\hline Acetaldehyde & $661^{1, a}$ & Carvone & $1640^{1, a}$ & Eugenol & $1930^{1, a}, 500^{2, b}, 72^{2, c}$ \\
\hline 2-Methylbutanal & $6400^{1, a}$ & Myrtenal & $2300^{1, a}, 170^{2, c}$ & Methyl eugenol & $810^{1, \mathrm{a}}, 540^{2, \mathrm{~b}}, 112^{2, \mathrm{c}}$ \\
\hline 3-Methylbutanal & $5600^{1, a}, 4750^{2, a}$ & Camphor & $1310^{2, a}, 3000^{2, b}$ & $\gamma$-Butyrolactone & $1540^{1, \mathrm{a}}, 1000^{1, \mathrm{~b}}$ \\
\hline Furfural & $65^{1, \mathrm{a}}, 20^{1, \mathrm{~b}}$ & 1-Terpineol & $4300^{1, a}$ & $\gamma$-Nonalactone & $6600^{1, a}$ \\
\hline
\end{tabular}

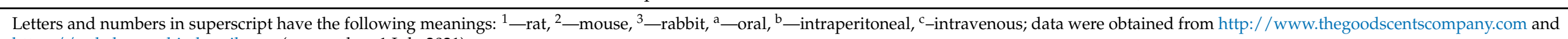
https:/ / pubchem.ncbi.nlm.nih.gov (accessed on 1 July 2021). 


\section{Encapsulation and Selection of Flavor Compounds Carriers}

\subsection{Encapsulation}

Encapsulation is a technology developed in the 1960s, and the purpose of encapsulation was the retention of the flavor compounds during storage of products, protection from oxidation reactions, the extension of the shelf-life of the flavor and controlled release [28-30]. The encapsulated material (pure substances or a mixture) is known as coated material, core material, payload, internal phase, fill or actives, while the coating material is called a shell, wall material, capsule, carrier, membrane, film, the outer shell or packing material [16,31]. Different shapes of microcapsules can be formed, and their morphology depends on the arrangement of the coated material and the deposition process of the wall material. In the food and pharmaceutical industries, microencapsulation has been widely used, while recently nanoencapsulation had attracted increasing attention due to better encapsulation efficiency, stability and more successful controlled release of the encapsulated material [30]. The obtained encapsulates can be in the form of powder, liquid or paste, depending on the applied technique. Their purpose is different; for example, the powder form of encapsulated flavor is mainly used in the bakery industry [30].

Different methods for the encapsulation of food ingredients are available, and they include: emulsification (high-pressure homogenization, microfluidization, ultrasonic technique, spontaneous emulsification, phase inversion emulsification, miscellaneous emulsification techniques), spray drying, spray chilling/cooling, electro-spinning and electrospraying, freeze-drying, spray-freeze-drying, extrusion, coacervation, fluid bed coating and molecular inclusion in cyclodextrins. They can be divided into chemical (e.g., molecular inclusion), physico-chemical (e.g., emulsification) and physico-mechanical methods (e.g., freeze-drying) [30].

\subsection{Flavor Carriers}

The selection of a coating material depends on its nature, application of the final product and the encapsulation process [30]. The most common carriers of flavor compounds are polysaccharides (e.g., maltodextrins, $\beta$-cyclodextrins, modified starches), proteins, lipids, synthetic polymers and their combinations [32,33]. The process of selecting flavor compounds carriers is demanding and should be carried out carefully in order to avoid negative consequences. In addition to this, some flavor compounds are poorly retained while some are firmly entrapped, resulting in an uneven flavor. This is a challenge for the food industry, and solutions can be found in the understanding of interactions that take place between the flavor compounds and their carriers [32]. The importance of the carrier selection for the encapsulation efficiency of certain flavor compounds was shown in a study by Zhang et al. [4] where ethyl butyrate and hexanal were encapsulated by $\beta$-cyclodextrin and $\gamma$-cyclodextrin. It was observed that the ethyl butyrate $/ \gamma$-cyclodextrin complex had the highest inclusion efficiency followed by ethyl butyrate/ $\beta$-cyclodextrin, hexanal $/ \beta$-cyclodextrin and hexanal $/ \gamma$-cyclodextrin complexes. There are many factors that affect the formation of complexes, such as matching cyclodextrin cavity and payload molecules and the polarity of payload molecules, environmental factors. In this case, for ethyl butyrate, the cavity of $\gamma$-cyclodextrin was more suitable, while for hexanal, $\beta$ cyclodextrin was better. Ethyl butyrate is a less polar molecule than hexanal, and the aqueous complexation medium that was used favored the entry of less polar payload molecules into the hydrophobic cavity of cyclodextrin. Further, it was observed that during storage, hexanal complexes had better stability [4]. It can be observed that each component will behave differently during encapsulation but also during storage, depending on the carrier material. Additionally, a contribution that can be achieved through the incorporation of flavor compounds into a food product is of high importance for the quality of the particular product, but also for consumer satisfaction in general [33]. 


\subsection{Flavor Retention}

Retention of flavor during the encapsulation process depends on the following factors [30,34-41]:

- Flavor compound characteristics: the type of compounds (e.g., ketones, esters, acids), polarity, size, molecular weight, relative volatility, concentration;

- Carrier characteristics: the type of carrier (e.g., proteins, fats, polysaccharides), molecular weight, viscosity, solids content, glass transition temperature, solubility, emulsifying ability, film-forming capability, concentration, biocompatibility;

- The method of sample preparation: emulsification method, emulsion droplet size, emulsion viscosity, emulsion stability;

- Applied encapsulation methods (e.g., spray-drying, extrusion) and

- Operating parameters during encapsulation: feed flow rate, inlet and outlet air temperature, air flow rate, type of atomizer.

In the food industry, polysaccharides are used as sweeteners, thickeners and/or gelling agents. Due to their broad application range, they are often found in foods together with flavor compounds and have a strong impact on them. There are many properties of flavor compounds that affect their interactions with other components present in foods, and those that need to be emphasized are the molecular size, shape, volatility and functional groups [3].

\section{Polysaccharides-Flavor Interactions}

\subsection{Starch-Flavor Compounds Interactions}

Starch is one of the main food components of plant origin used as an additive for thickening and stabilization. It is composed of glucopyranose units, and its main components are amylose (linear polymer) and amylopectin (short, branched chains), whose ratio affects the physical properties of a particular starch. Furthermore, starches can also serve as carriers for encapsulation of flavor compounds and thus contribute to flavor quality [42,43]. Starch interacts with flavor compounds, and these interactions depend on various factors such as polarity, molecular weight, hydrophobicity, volatility and solubility of flavor compounds, nature of the starch and competition among flavor compounds [43-45]. The formation of helical inclusion complexes was reported as an example of the specific binding of starch (especially the linear amylose) and flavor compounds in such a way that the flavor molecules are wrapped in a left-handed single helical structure $[10,46]$. These types of complexes with starch were reported for aldehydes, alcohols, terpenes, ketones and fatty acids $[42,47]$. Although it was stated that amylopectin might also be partially involved in complex formation, other studies indicated that starch with a higher amylopectin content did not form inclusion complexes or form a less [48,49]. The second type of interaction between starch and flavor compounds included polar interactions. It was emphasized that hydrogen bonds were formed between the hydroxyl groups of starch and flavor compounds $[16,50,51]$. Additionally, powdered starch is porous on its surface, and the flavor compounds can be retained on such surfaces by physical sorption [50]. This mode of interaction is more important for high concentrations of flavor compounds [46]. Sometimes flavor retention cannot be explained by the formation of an inclusion complex with amylose, and in those cases, interactions with amylopectin due to adsorption (including hydrogen bonds) are more likely to occur [5].

In the study conducted by Tietz et al. [46], there were no competitive interactions of flavor compounds and starch, and a possible reason for this was that very low concentrations of flavor compounds had been used, while the binding capacity of starch is 100 times higher. Furthermore, in systems with low water content and different types of starch, retention of flavor increased with the polarity of flavor compounds. Additionally, granular starch retained less flavor, and the reason may be in the lower availability of starch molecules [27]. Table 3 provides an overview of studies that investigated the formation of complexes between flavor compounds and starch and their interactions. 
Table 3. Flavor compounds complexed with starch.

\begin{tabular}{|c|c|c|c|c|}
\hline Flavor Compounds & Type of Starch & Applied Technique & Applied Methods of Analysis & Reference \\
\hline $\begin{array}{l}\text { D-limonene, ethyl hexanoate, octanal and } \\
\text { 1-hexanol }\end{array}$ & Seven different starch materials & Extrusion & Inverse gas chromatography & {$[51]$} \\
\hline $\begin{array}{l}\text { 1-Hexanol, 2-hexanol, D-limonene, ethyl } \\
\text { hexanoate and octanal }\end{array}$ & Native corn starch & Not specified & Inverse gas chromatography & {$[50]$} \\
\hline Vanillin & $\begin{array}{l}\text { Oxidized starch from corn and waxy } \\
\text { amaranth starch }\end{array}$ & Spray-drying & Spectrophotometric analysis & {$[52]$} \\
\hline Hexanal and menthone & Non-modified and modified tapioca starch & Not specified & $\begin{array}{l}\text { Proton transfer reaction mass } \\
\text { spectrometry }\end{array}$ & [46] \\
\hline $\begin{array}{l}\text { Methyl phenylacetate, 3-hexanol, ethyl } \\
\text { 2-methylbutanoate, ethyl pentanoate, } \\
\text { methyl hexanoate, ethyl hexanoate, hexyl } \\
\text { acetate, isopropyl propionate, ethyl } \\
\text { butanoate and ethyl 3-methylbutanoate }\end{array}$ & Different commercially available starches & Not specified & $\begin{array}{l}\text { Gas chromatography-mass } \\
\text { spectrometry analysis with solid-phase } \\
\text { micro-extraction }\end{array}$ & [43] \\
\hline Menthone & Starch & Freeze-drying & $\begin{array}{l}\text { Transmission electron microscopy, } \\
\text { dynamic light scattering, X-ray } \\
\text { diffraction, differential scanning } \\
\text { calorimetry, Fourier transform infrared } \\
\text { spectroscopy, high-performance size } \\
\text { exclusion chromatography }\end{array}$ & [53] \\
\hline Menthol & $\begin{array}{l}\text { Modified starch, gelatin, oil-gelatin } \\
\text { emulsion and aquacoat }\end{array}$ & Spray-drying & $\begin{array}{l}\text { Headspace gas chromatography, } \\
\text { encapsulation efficiency, dynamic } \\
\text { viscosity, density, tension }\end{array}$ & {$[54]$} \\
\hline Ethyl acetate, R-(+)-limonene and hexanal & Waxy maize starch and potato starch & Not specified & $\begin{array}{l}\text { Headspace gas chromatography-mass } \\
\text { spectrometry }\end{array}$ & [55] \\
\hline $\begin{array}{l}\text { 1-Decanol, 1-decanal, 1-naphthol, } \\
\text { decanoic acid, } \delta \text {-decalactone, L-menthone, } \\
\text { L-menthol, } \Gamma \text {-decalactone and thymol }\end{array}$ & High-amylose maize starch & Freeze-drying & $\begin{array}{l}\text { X-ray diffraction, differential scanning } \\
\text { calorimetry, Fourier transform infrared } \\
\text { spectroscopy, solid-state }{ }^{13} \mathrm{C} \text { nuclear } \\
\text { magnetic resonance spectroscopy and } \\
\text { molecular dynamics simulation }\end{array}$ & [10] \\
\hline $\begin{array}{l}\text { 1-Hexanol, hexanal, trans-2-hexanal and } \\
\text { 2-hexanone }\end{array}$ & Potato starch and corn starch & Not specified & $\begin{array}{c}\text { Differential scanning calorimetry and } \\
\text { X-ray diffraction }\end{array}$ & [44] \\
\hline
\end{tabular}


Table 3. Cont

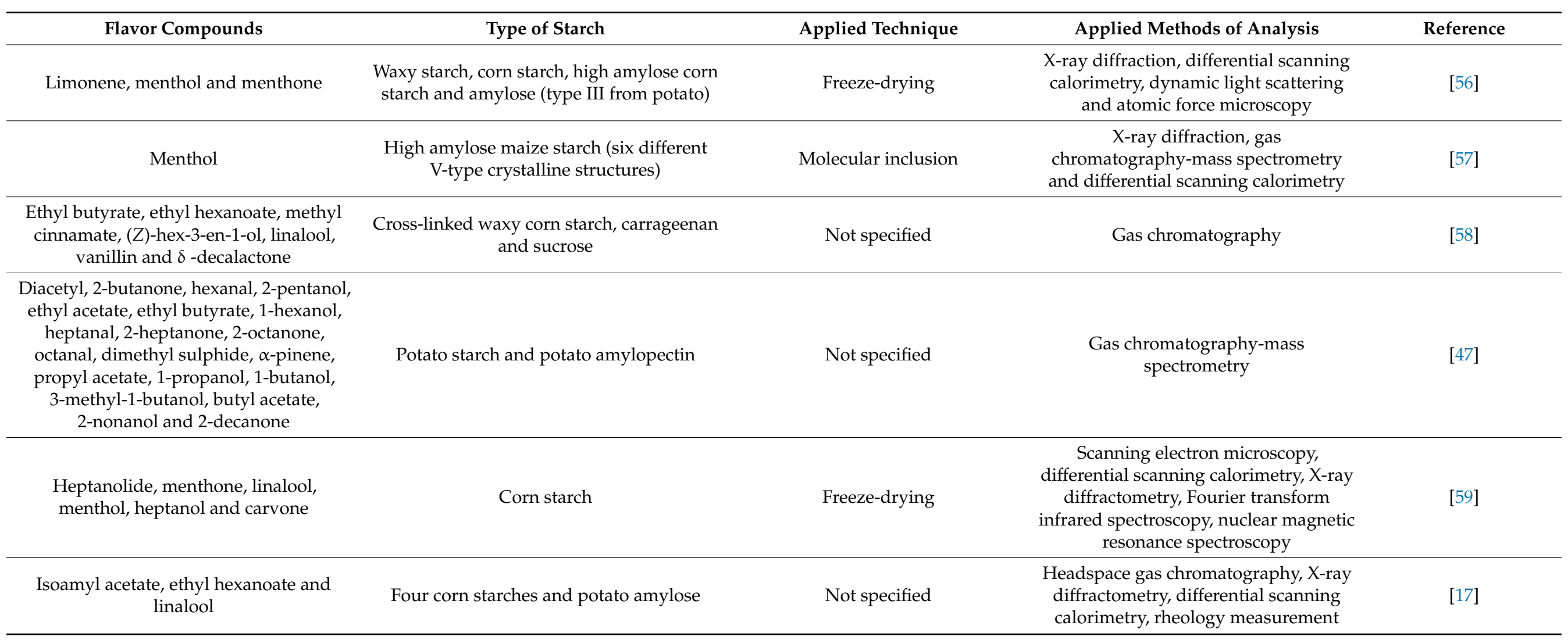




\subsection{Maltodextrin-Flavor Compounds Interactions}

Maltodextrin is obtained by acid or enzymatic hydrolysis of starch from various sources (corn, potato or others) and is a relatively inexpensive polysaccharide with a neutral taste [60]. It has low viscosity, high water solubility and is often used as an encapsulating material for the purpose of protecting flavor compounds from physical and chemical changes [61]. The main disadvantage in its application is its weak emulsifying capacity and low retention of flavor compounds [28], so it is often used in a mixture with other polysaccharides. Commercially, maltodextrin is available in different dextrose equivalent (DE) grades, which represent the degree of starch hydrolysis. Previous studies had shown that flavor retention depended on the DE of maltodextrin, but later it was found that use of the DE value was not adequate for predictions of maltodextrins performance [16]. Additionally, it has been observed that temperature, as one of the environmental factors, may have an effect on the retention or release of flavor compounds in polysaccharide systems. In maltodextrin solution (DE $5 ; 10 \%, w / w)$, retention of studied compounds (1-hexanol, 2-butanone, 2-hexanone, hexanal, 2-octanone, ethyl butanoate, 2-heptanone) was better at higher temperatures $\left(80^{\circ} \mathrm{C}\right)$, indicating a hydrophobic effect [62]. As for the mechanisms responsible for the interactions of maltodextrin and flavor compounds, mechanisms described for starch, involving the formation of an inclusion complex and polar interactions, can also be applied in this case $[3,63]$. Table 4 shows some studies that examined the effect of maltodextrin on flavor compounds.

Table 4. Flavor compounds complexed with maltodextrin.

\begin{tabular}{|c|c|c|c|c|}
\hline Flavor Compounds & Used Material & Applied Technique & Applied Methods of Analysis & Reference \\
\hline $\begin{array}{l}\text { 1-Propanol, diacetyl, } \\
\text { 2-pentanone, hexanal and } \\
\text { 2-heptanone }\end{array}$ & Maltodextrin & Freeze-thawing & $\begin{array}{l}\text { Differential scanning calorimetry, } \\
\text { gas chromatography headspace } \\
\text { analysis, creaming stability, } \\
\text { Microstructural observation, } \\
\text { oiling off, emulsion flavoring } \\
\text { and particle size analysis }\end{array}$ & {$[63]$} \\
\hline Asparagus juice flavor & Maltodextrin & Spray-drying & $\begin{array}{l}\text { Gas chromatography-mass } \\
\text { spectrometry, moisture content, } \\
\text { glass transition temperature, } \\
\text { particle size distribution, } \\
\text { morphology }\end{array}$ & {$[64]$} \\
\hline Citral & $\begin{array}{c}\text { Maltodextrin, sucrose and } \\
\text { trehalose }\end{array}$ & Spray-drying & $\begin{array}{l}\text { Droplet size, viscosity, molecular } \\
\text { mobility, microstructure }\end{array}$ & {$[35]$} \\
\hline $\begin{array}{l}\text { Picrocrocin, safranal and } \\
\text { crocin }\end{array}$ & $\begin{array}{l}\text { Maltodextrin, pectin and } \\
\text { whey protein concentrate }\end{array}$ & Multiple emulsification & $\begin{array}{l}\text { Emulsion droplet size analysis, } \\
\text { stability measurement, } \\
\text { encapsulation efficiency and } \\
\text { release characteristics }\end{array}$ & {$[65]$} \\
\hline $\begin{array}{l}\text { Picrocrocin, safranal and } \\
\text { crocin }\end{array}$ & $\begin{array}{l}\text { Maltodextrin, gum arabic } \\
\text { and gelatine }\end{array}$ & Spray-drying & $\begin{array}{l}\text { Encapsulation efficiency, powder } \\
\text { yield determination, moisture } \\
\text { content, scanning electron } \\
\text { microscopy }\end{array}$ & {$[66]$} \\
\hline Orange terpenes & Maltodextrin and sucrose & $\begin{array}{l}\text { Hot melt counter-rotating } \\
\text { extrusion }\end{array}$ & $\begin{array}{l}\text { Differential scanning calorimetry, } \\
\text { X-ray diffractometry, gas } \\
\text { chromatography, incident light } \\
\text { and polarization microscopy }\end{array}$ & {$[67]$} \\
\hline Orange terpenes and carvacrol & Maltodextrin and sucrose & Batch mixing & $\begin{array}{l}\text { Water content, differential } \\
\text { scanning calorimetry, X-ray } \\
\text { diffractometry and gas } \\
\text { chromatography }\end{array}$ & {$[68]$} \\
\hline $\begin{array}{l}\text { Isoamyl acetate, allyl caproate, } \\
\text { linalool, orange oil and citral }\end{array}$ & $\begin{array}{l}\text { Gum arabic, maltodextrin } \\
\text { and sodium caseinate }\end{array}$ & Spray-drying & $\begin{array}{l}\text { Gas chromatography-mass } \\
\text { spectrometry, scanning electron } \\
\text { microscopy, physical properties } \\
\text { (encapsulation efficiency, } \\
\text { viscosity, moisture, emulsion } \\
\text { stability), nonenzymatic } \\
\text { browning }\end{array}$ & {$[69]$} \\
\hline
\end{tabular}


Table 4. Cont

\begin{tabular}{|c|c|c|c|c|}
\hline Flavor Compounds & Used Material & Applied Technique & $\begin{array}{c}\text { Applied Methods of } \\
\text { Analysis }\end{array}$ & Reference \\
\hline $\begin{array}{c}\text { 1,8-Cineole, camphor and } \\
\alpha \text {-pinene }\end{array}$ & $\begin{array}{l}\text { Maltodextrin, gum } \\
\text { arabic, modified starch, } \\
\text { inulin }\end{array}$ & Spray-drying & $\begin{array}{l}\text { Gas chromatography-mass } \\
\text { spectrometry, differential } \\
\text { scanning calorimetry, } \\
\text { scanning electron } \\
\text { microscopy, characterization } \\
\text { of the microcapsules } \\
\text { (wettability and solubility, } \\
\text { moisture content, bulk } \\
\text { density, oil retention) }\end{array}$ & {$[60]$} \\
\hline Cocoa flavor & $\begin{array}{l}\text { Maltodextrin and } \\
\text { Hi-Cap } 100\end{array}$ & Spray-drying & $\begin{array}{l}\text { Gas chromatography- } \\
\text { olfactometry, gas } \\
\text { chromatography-mass } \\
\text { spectrometry, Fourier } \\
\text { transform infrared } \\
\text { spectroscopy, process yield, } \\
\text { moisture and water activity, } \\
\text { tapped density, } \\
\text { hygroscopicity, water } \\
\text { solubility index and water } \\
\text { absorption index, color } \\
\text { parameters, morphology and } \\
\text { size particle, sensory } \\
\text { evaluation }\end{array}$ & [39] \\
\hline $\begin{array}{l}\text { Orange oil flavor } \\
\text { compounds }\end{array}$ & $\begin{array}{c}\text { Maltodextrin, sucrose, } \\
\text { trehalose, lactose, } \\
\text { modified starch and } \\
\text { gum arabic }\end{array}$ & Spray-drying & $\begin{array}{l}\text { Electronic nose and sensory } \\
\text { analysis }\end{array}$ & [70] \\
\hline
\end{tabular}

\subsection{Pectin-Flavor Compounds Interactions}

Pectin is a complex mixture of polysaccharides, consisting of D-galacturonic acid units linked by $\alpha(1 \rightarrow 4)$ glycosidic bonds [71]. It is present in the middle lamella of the cell wall of fruits and vegetables. Monomeric sugar molecules (galactose, arabinose or rhamnose) that are esterified or acetylated are responsible for the heterogeneous structure of pectin [72]. The use of pectin is as an agent for gelling, thickening, stabilizing, emulsifying purposes, and can be applied in both food and pharmaceutical industries [73-75]. According to the degree of esterification (DE), pectins are divided into high-esterified (DE $>50 \%$ ) and lowesterified ( $\mathrm{DE}<50 \%)$ pectins [75]. Due to its carboxyl groups, pectin is an ionic molecule, and therefore, its thickening properties depend on the degree of esterification, $\mathrm{pH}$, the presence of bivalent metal ions and the arrangement of free carboxyl groups [76].

In a study conducted by Guichard et al. [77], it was observed that the addition of pectin to jam had the effect of reducing the intensity of taste, which can be explained by the slower diffusion of flavor compounds trapped in the pectin. To describe the interactions between flavor compounds and pectin, Braudo et al. [78] investigated four commonly present flavor compounds in foods (2-acetyl pyridine, 2-acetyl tiophene, 2,3-diethyl pyrazine and 2-octanone) and low-esterified pectin. Heterocyclic flavor compounds were not adsorbed on low-esterified pectin in a neutral medium, but in an acidic medium; the adsorption took place through hydrogen bonds. These bonds were formed between the aromatic ring of the flavor compound and the hydrogen atoms on the carboxyl group of pectin. In the neutral medium, 2-octanone was adsorbed on low-esterified pectin by van der Waals interactions, while in the acidic medium, the adsorption took place via hydrophobic interactions. It was observed that the binding of heterocyclic flavor compounds to lowesterified pectin increased with decreasing $\mathrm{pH}$ (from 4.0 to 3.0), while at $\mathrm{pH} 3.0$, the maximum was reached at a concentration of $0.6-0.7 \%$ of low-esterified pectin, followed 
by a decrease. Two explanations for this phenomenon were proposed: binding of pectin molecules to each other and binding of flavor compounds to pectin, and both of them included hydrogen bonds. Additionally, this group of scientists examined the effect of essential metal ions $\left(\mathrm{Ca}^{2+}, \mathrm{Zn}^{2+}, \mathrm{Mg}^{2+}\right.$ and $\left.\mathrm{Fe}^{3+}\right)$ on the nature of binding of previously mentioned flavor compounds to low-esterified pectin. It was observed that metal ions prevented the adsorption of heterocyclic flavor compounds on low-esterified pectin in an acidic medium due to their interaction with carboxyl groups of low-esterified pectin. The carboxyl groups of pectin that interacted with metal ions were not able to form hydrogen bonds with flavor compounds. The presence of metal ions inhibited the binding of 2-octanone to low-esterified pectin in acidic media, while in neutral media, it had no effect [78].

There is an increasing demand for low-fat products in the marketplace, but there are changes in flavor release, flavor perception, structure and appearance in such products. To make up for the shortcomings caused by fat removal, fat substitutes such as maltodextrin, starch and carrageenan are used. In a study conducted by Tromelin et al. [1], the effect of pectin and carrageenan on flavor retention was examined. It was determined that iota-carrageenan altered the interactions of water molecules and flavor compounds (ethyl propanoate, ethyl trans-2-butenoate, 3-methylbutyl acetate, isopropyl 2-methyl-2butenoate, ethyl hexanoate, ethyl heptanoate, butyl pentanoate, 4-methylpent-3-en-2-one, 4-methylpentan-2-one, heptan-2-one, 2,6-dimethylheptan-4-one, trans-2-methyl-2-butenal, 2-ethylbutanal), while pectin caused weak changes in these interactions.

\subsection{Cyclodextrin-Flavor Compounds Interactions}

Cyclodextrins are naturally occurring cyclic oligosaccharides composed of $\alpha$-D-glucopyranose units linked by $\alpha(1 \rightarrow 4)$ glycosidic bonds. $\alpha-(6 \alpha$-D-glucopyranose units), $\beta$-(7 units) and $\gamma$ cyclodextrins ( 8 units) are the most important for the food industry [79]. For better illustration, it can be said that cyclodextrin is a "shallow truncated cone", whose cavity can serve to form complexes with other molecules. The outer surface of cyclodextrins is hydrophilic while their interior, i.e., the cavity, is hydrophobic [80]. Due to its specific structure, cyclodextrin has the ability to form non-covalent bonds with various organic and inorganic (guest) molecules [14]. An interesting fact is that the depth of the cavity in cyclodextrins is approximately equal while the diameter of the cavities increases in $\alpha$-cyclodextrin, $\beta$-cyclodextrin and $\gamma$-cyclodextrin, respectively [14,81]. An example of the effect of a larger cavity diameter in $\beta$-cyclodextrin than in $\alpha$-cyclodextrin was shown in the measurement of the binding constants of 14 flavor compounds on these two cyclodextrins. The binding constant (determined by UV/Vis spectroscopy) of all flavor compounds (maltol, furaneol, methyl cinnamate, vanillin, cineole, geraniol, citral, camphor, menthol, eugenol, nootkatone, limonene, $p$-vinil and guaiacol) to $\beta$-cyclodextrin was higher than was the case of $\alpha$-cyclodextrin. This phenomenon was explained by hydrophobic/hydrophilic interactions [14].

$\beta$-cyclodextrins have the ability to protect flavor compounds from oxidation and also from chemical and thermal degradation. In a study by Goubet et al. [32], six flavor compounds (benzyl alcohol, 2-methylbutyric acid, hexanoic acid, hexanol, ethyl hexanoate, ethyl propionate) and their retention on $\beta$-cyclodextrin were studied. They observed that the retention of benzyl alcohol was $2 \mathrm{~mol} / \mathrm{mol}$ of $\beta$-cyclodextrin, while for the other five aliphatic flavor compounds, the retention was $1 \mathrm{~mol} / \mathrm{mol}$ of $\beta$-cyclodextrin, which would mean that the aromatic ring had an effect on binding with $\beta$-cyclodextrin. Similar results were obtained in the research of Sanemasa et al. [82]. They observed that the retention of benzene and fluorobenzene was $1.9 \mathrm{~mol} / \mathrm{mol}$ of $\beta$-cyclodextrin, while the retention of heptane and pentane was approximately $1 \mathrm{~mol} / \mathrm{mol}$ of $\beta$-cyclodextrin (more precisely, 0.88 and $1.1 \mathrm{~mol} / \mathrm{mol}$ of $\beta$-cyclodextrin, respectively) [82].

Tobitsuka et al. [83] conducted a study to obtain data on the retention of pear [La France (Pyrus communis L.)] flavor compounds in cyclodextrin, i.e., to investigate the interactions between aliphatic acetate esters and cyclodextrin. Structural analysis of complexes ( $\alpha$-cyclodextrin-butyl acetate and $\alpha$-cyclodextrin-hexyl acetate) by NMR spectroscopy showed that there were cross-peaks between protons in $\alpha$-D-glucopyranose and protons 
of the alkyl chain of esters. The aforementioned $\alpha$-D-glucopyranose protons are located within the cyclodextrin cavity (at the 3- and 5-position), indicating that the esters were included in the $\alpha$-cyclodextrin cavity.

Sometimes it is necessary to remove some compounds from the final product because they can cause undesirable off-flavors. Such problems can occur during the preservation of watermelon juice by thermal treatments. Yang et al. [84] tried to remove unwanted flavor compounds of watermelon juice using $\beta$-cyclodextrin, xanthan gum, sugar/acid and carboxymethyl cellulose sodium. It has been shown that $\beta$-cyclodextrin had the best effect on improving the sensory quality of watermelon juice by effectively reducing 1-octanol, (E)-2-octanol, decanal and (E)-2-decenal by $22.81 \%, 36.43 \%, 50.82 \%$ and $28.19 \%$, respectively. Changes in intensity of stretching vibration bands determined by FT-IR analysis suggested the formation of non-covalent bonds (hydrogen bonds) between $\beta$-cyclodextrin and (E)-2decenal or 1-octanol.

Cyclodextrins are some of the most common carriers of flavor compounds, and Table 5 presents an overview of flavor compounds complexed with different types of cyclodextrins.

Table 5. Flavor compounds complexed with cyclodextrin.

\begin{tabular}{|c|c|c|c|c|}
\hline Flavor Compounds & Type of Cyclodextrin & Applied Technique & Applied Method of Analysis & Reference \\
\hline $\begin{array}{c}\text { Menthol, D-limonene, } \\
\text { (+)-limonene, (-)-limonene, } \\
\text { hydroxycitronellal, } \\
\text { (+/-)-linalyl acetate, } \alpha \text {-ionone, } \\
\text { vanillin and } \gamma \text {-decalactone }\end{array}$ & $\beta$-cyclodextrin & $\begin{array}{l}\text { Crystallization from the } \\
\text { ethanol-water solution }\end{array}$ & $\begin{array}{l}\text { Gas chromatography and } \\
\text { thermal gravimetric analysis }\end{array}$ & {$[85]$} \\
\hline Thymol and cinnamaldehyde & $\beta$-cyclodextrin & Freeze-drying & $\begin{array}{l}\text { Differential scanning calorimetry, } \\
\text { release studies, moisture } \\
\text { sorption properties }\end{array}$ & [86] \\
\hline $\begin{array}{c}\text { Thymol and thyme essential } \\
\text { oil }\end{array}$ & $\beta$-cyclodextrin & $\begin{array}{l}\text { Freeze-drying and } \\
\text { kneading }\end{array}$ & $\begin{array}{l}\text { Entrapment efficiency, } \\
\text { differential scanning calorimetry, } \\
\text { phase solubility, particle size and } \\
\text { morphology }\end{array}$ & [87] \\
\hline$\alpha$-Terpineol & $\begin{array}{l}\beta \text {-cyclodextrin, } \\
\text { 2-hydroxypropyl- } \beta \text { - } \\
\text { cyclodextrin }\end{array}$ & Freeze-drying & $\begin{array}{c}\text { Differential scanning calorimetry, } \\
\text { scanning electron microscopy, } \\
\text { water sorption isotherms and } \\
\text { water content analysis, storage } \\
\text { study }\end{array}$ & {$[88,89]$} \\
\hline Linalool & $\begin{array}{l}\text { 2-hydroxypropyl- } \beta \text { - } \\
\text { cyclodextrin }\end{array}$ & Freeze-drying & $\begin{array}{l}\text { High-performance liquid } \\
\text { chromatography, }{ }^{1} \mathrm{H} \text { NMR } \\
\text { spectroscopy, circular dichroism } \\
\text { spectroscopy, solubility, stability } \\
\text { and release profiles studies }\end{array}$ & {$[90]$} \\
\hline (+)-Linalool and (-)-linalool & $\alpha$ - and $\beta$-cyclodextrin & $\begin{array}{l}\text { Crystallization from the } \\
\text { ethanol-water solution }\end{array}$ & $\begin{array}{l}\text { Gas chromatography and } \\
\text { thermal gravimetric analysis }\end{array}$ & {$[85]$} \\
\hline $\begin{array}{l}\text { (+)-Isopulegole and } \\
\text { (-)-isopulegole }\end{array}$ & $\beta$-cyclodextrin & Molecular inclusion & $\begin{array}{l}\text { High-performance liquid } \\
\text { chromatography, X-ray } \\
\text { crystallography }\end{array}$ & {$[91]$} \\
\hline Eugenol & $\begin{array}{l}\alpha-, \beta-, \gamma-\text { and } \\
\text { 2-hydroxypropyl- } \beta- \\
\text { cyclodextrin }\end{array}$ & Freeze-drying & $\begin{array}{l}\text { Fourier transform infrared } \\
\text { spectroscopy, differential } \\
\text { scanning calorimetry, thermal } \\
\text { gravimetric analysis }\end{array}$ & [92] \\
\hline Eugenol & $\beta$-cyclodextrin & Freeze-drying & $\begin{array}{l}\text { Oxidative differential scanning } \\
\text { calorimetry, particle size analysis } \\
\text { and morphology, entrapment } \\
\text { efficiency, phase solubility } \\
\text { studies }\end{array}$ & [93] \\
\hline Ethyl benzoate & $\begin{array}{l}\text { 2-hydroxypropyl- } \\
\beta \text {-cyclodextrin }\end{array}$ & Freeze-drying & $\begin{array}{l}\text { UV/Vis spectroscopy, Fourier } \\
\text { transform infrared spectroscopy, } \\
\text { phase solubility, molecular } \\
\text { modeling and controlled release } \\
\text { studies }\end{array}$ & [94] \\
\hline
\end{tabular}


Table 5. Cont.

\begin{tabular}{|c|c|c|c|c|}
\hline Flavor Compounds & Type of Cyclodextrin & Applied Technique & $\begin{array}{c}\text { Applied Method of } \\
\text { Analysis }\end{array}$ & Reference \\
\hline Estragole & $\begin{array}{l}\quad \alpha-, \beta-, \gamma-, \\
\text { 2-hydroxypropyl- } \beta-, \\
\text { low methylated- } \beta \text { and } \\
\text { randomly methylated- } \\
\beta \text {-cyclodextrin }\end{array}$ & Freeze-drying & $\begin{array}{c}\text { Static headspace gas } \\
\text { chromatography, UV/Vis } \\
\text { spectroscopy, }{ }^{1} \mathrm{H} \text { NMR } \\
\text { spectroscopy, encapsulation } \\
\text { efficiency, differential } \\
\text { scanning calorimetry, Fourier } \\
\text { transform infrared } \\
\text { spectroscopy }\end{array}$ & [95] \\
\hline Citronellal and citronellol & $\beta$-cyclodextrin & Kneading & $\begin{array}{l}\text { Gas chromatography-mass } \\
\text { spectrometry, scanning } \\
\text { electron microscopy, Fourier } \\
\text { transform infrared } \\
\text { spectroscopy, differential } \\
\text { scanning calorimetry }\end{array}$ & [96] \\
\hline $\begin{array}{l}\text { L-Menthol, ethyl butyrate, } \\
\text { ethyl hexanoate, citral, } \\
\text { benzaldehyde and methyl } \\
\text { anthranilate }\end{array}$ & $\begin{array}{c}\alpha-, \beta-\text { and } \\
\gamma \text {-cyclodextrin }\end{array}$ & Molecular inclusion & $\begin{array}{l}\text { Headspace gas } \\
\text { chromatography and sensory } \\
\text { evaluation }\end{array}$ & [97] \\
\hline $\begin{array}{l}\text { Turmeric extract } \\
\text { (Curcuminoids) }\end{array}$ & $\begin{array}{l}\beta \text {-cyclodextrin and } \\
\text { brown rice flour }\end{array}$ & Spray-drying & $\begin{array}{l}\text { Gas chromatography-mass } \\
\text { spectrometry, } \\
\text { high-performance liquid } \\
\text { chromatography, product } \\
\text { recovery, moisture content, } \\
\text { hygroscopicity, } \\
\text { encapsulation efficiency, } \\
\text { scanning electron } \\
\text { microscopy, sensory analysis }\end{array}$ & [38] \\
\hline Geraniol & $\begin{array}{c}\gamma \text {-cyclodextrin and } \\
\text { polyvinyl alcohol }\end{array}$ & Electro-spinning & $\begin{array}{l}\text { X-ray diffraction, thermal } \\
\text { gravimetric analysis, }{ }^{1} \mathrm{H} \\
\text { NMR spectroscopy, scanning } \\
\text { electron microscopy }\end{array}$ & [98] \\
\hline $\begin{array}{l}\text { Sweet orange flavor (sweet } \\
\text { orange oil, ethyl maltol, } \\
\text { decanal, linalool, lemon oil, } \\
\text { carvone, ethyl butyrate and } \\
\text { benzyl alcohol) }\end{array}$ & $\beta$-cyclodextrin & Molecular inclusion & $\begin{array}{c}\text { Thermal gravimetric analysis } \\
\text { and optical microscopy } \\
\text { analysis }\end{array}$ & [99] \\
\hline
\end{tabular}

\subsection{Guar Gum-Flavor Compounds Interactions}

Gums are used to increase product viscosity, and it has been observed that highly volatile components were greatly affected by changes in viscosity $[76,100]$. The addition of carboxymethyl cellulose or guar gum reduced the volatility of highly volatile nonpolar flavor compounds such as $\alpha$-pinene, 1,8-cineole, ethyl 2-methylbutyrate, while less volatile components such as 2-methoxy-3-methylpyrazine, vanillin, methyl anthranilate and maltol did not exhibit this phenomenon [76]. Additionally, the addition of guar gum or carboxymethyl cellulose reduced the release of limonene, hexanal, dimethyl sulfide, ethylbenzene, ethylsulfide, hexanone and styrene from model flavor solutions [100]. A group of scientists studied the effect of guar gum on the retention of flavor compounds. Guar gum samples differed in the galactose/mannose ratio, which can be attributed to different origins of plant seeds from which the guar gum was extracted. It was observed that the retention of ethyl hexanoate significantly depended on the galactose/mannose ratio, which can be attributed to the influence of hydrogen bonds. The retention of ethyl decanoate (which is a non-polar molecule) depended on the molecular weight of guar gum and hydrophobic interactions [101]. 


\subsection{Gum Arabic-Flavor Compounds Interactions}

Gum arabic is one of the common materials used to encapsulate flavor compounds due to its solubility, good retention of flavor compounds and low viscosity. It is also important to note that it is more expensive than some other materials (such as maltodextrin), which limits its use in the food industry [102-104]. Interactions between flavor compounds and gums take place via hydrogen bonds, and their applications in food products are for flavor stabilization [3]. During the encapsulation of a mixture of ethyl butyrate, orange oil, ethyl propionate, benzaldehyde and cinnamic aldehyde in maltodextrin and gum arabic, better retention occurred when the proportion of gum arabic increased [28]. In a study conducted by Apintanapong and Noomhorm [105], 2-acetyl-1-pyrroline was encapsulated by spray drying into maltodextrin and gum arabic, which served as a coating material, and the highest quality of the obtained capsules was achieved at a ratio of 30:70 of maltodextrin:gum arabic. Interactions that took place between guar gum and flavor compounds have also been studied by other scientists [106-108], and they concluded that the creation of hydrophobic interactions within complexes was responsible for flavor retention.

\subsection{Xanthan-Flavor Compounds Interactions}

Xanthan gum is an extracellular biopolymer made up of D-glucose units linked by $\beta$ 1,4 bonds as the main chain and two molecules of mannose and one molecule of glucuronic acid as linear side branches. It is able to form an internal hydrophobic region into which flavor compounds can fit and thus prevent their release [109]. As the possible bond between xanthan and 1-octen-3-ol, the formation of hydrogen bond between the hydroxyl group of 1-octen-3-ol and oxygen from carbonyl on xanthan can occur [110]. Guichard and Etiévant [111] made the same assumption for the binding of xanthan and 1-octen-3-ol, and also assumed the formation of hydrogen bonds between the hydroxyl groups on xanthan and oxygen on 2-acetyl pyrazine. In a study conducted by Yang et al. [109], the effect of xanthan on the release of flavor compounds was examined. The results obtained by SPME/GC-MS analysis indicated that the xanthan solution inhibited the release of flavor compounds, but differences between the individual components were also observed due to their different hydrophobicity (different $\log P$ value). Terpenes (D-limonene and $\alpha$-pinene) were retained highly in xanthan solutions, while aldehydes (hexenal and perillaldehyde) and esters (ethyl acetate and ethyl butyrate) are smaller hydrophobic molecules that have been released better from hydrophilic xanthan solutions. In a study by Kopjar et al. [112], retention of eugenol and linalool in hydrogels prepared with hydrocolloids (guar gum and xanthan) and the addition of trehalose and sucrose were investigated. It was observed that samples containing xanthan had lower retention of tested flavor compounds compared to the samples with guar gum. One reason for that may be the trapping of flavor compounds in the hydrophobic cavity of xanthan [113], but also during the preparation of hydrogels, hydrocolloids, sugars and water form complexes may exhibit different affinities for flavor compounds. Studies have shown that ethyl butanoate [101] and methyl butanoate [113] did not interact with xanthan, probably due to their low molecular weight and high solubility. The retention of ethyl hexanoate and ethyl decanoate in xanthan solutions was influenced by the proteins presented in xanthan, while molecular weight showed no effect. Additionally, the content of xanthan acetate groups had an effect on ethyl hexanoate [101].

Another study was conducted on the effect of adding xanthan gum to cloudy apple juice. Untrained panelists observed a difference even with a low amount $(0.5 \mathrm{~g} / \mathrm{L})$ of added xanthan gum and negatively rated the sample. They observed that with the addition of xanthan gum, the originality of apple juice and its typical flavor were lost [114].

\subsection{Cellulose-Flavor Compounds Interactions}

D-glucose units associated with $\beta(1 \rightarrow 4)$ linkages are the building blocks of cellulose. As the most abundant polysaccharide, cellulose is often used in various industries (chemical, food, biological and others). Due to its neutral taste and desirable effects on digestion, it is suitable as a food additive [115]. Unfortunately, cellulose application in the flavor 
industry is limited due to the strong intermolecular and intramolecular hydrogen bonds as well as van der Waals forces. Although flavor compounds can be adsorbed into the voids of cellulose chains, retention of these compounds is limited because of the reduced adsorptive capability of cellulose [115]. For these reasons, cellulose derivatives such as hydroxyethyl cellulose, carboxymethyl cellulose [100] and hydroxypropyl methylcellulose [116] were used for flavor compounds encapsulation.

Regenerated porous cellulose particles (RPC) increased the adsorption capacity of cellulose, and the possible use of such materials for encapsulation of L-menthol was investigated. Carboxymethyl cellulose (CMC) was used as the coating layer for RPC, and analyses (FTIR, SEM, G-C) showed that CMC had no effect on menthol content and encapsulation efficiency, while a positive effect on menthol retention during storage was observed. Finally, applied modifications indicated the possible use of these materials for encapsulation [115].

Vukoja et al. [33] carried out the complexation of raspberry juice flavor compounds with cellulose. It turned out that cellulose was a good carrier for flavor compounds of raspberry juice. Interactions that occurred between cellulose and flavor compounds might be through hydrogen bonds and van der Waals forces. The formation of hydrogen bonds was enabled because of hydrophilic regions of cellulose, which are formed when cellulose hydroxyl groups bind to the glucopyranose ring. Van der Waals forces are the result of hydrophobic regions formed due to the binding of $-\mathrm{CH}$ groups to the glucopyranose ring [33,117].

\section{9. $\beta$-Glucan-Flavor Compounds Interactions}

$\beta$-glucans are a group of polysaccharides composed of D-glucopyranosyl units connected by $\beta(1 \rightarrow 3)$ and $\beta(1 \rightarrow 4)$ linkages. They can be found in the cell walls of barley, oats, rye and wheat, but also in fungi, yeasts, algae and bacteria [118]. At neutral pH, they are soluble in water and form a viscous solution [72]. In a study conducted by Christensen et al. [119], the release of 12 esters and 3 alcohols selected from strawberry flavor in an aqueous solution with oat and barley $\beta$-glucan $(5,10$ and $15 \%)$ was examined. The increased concentration of $\beta$-glucan and higher molecular weights of the flavor components increased the retention of alcohols and esters. Better retention increase was observed with an increase in $\beta$-glucan concentration from $5 \%$ to $10 \%$ than in the range from $10 \%$ to $15 \%$, and oat $\beta$-glucan showed better retention of flavor compounds compared to barley $\beta$-glucan. Additionally, lower alcohol retention was attributed to the fact that alcohols can be hydrogen acceptors and donors while esters are only hydrogen donors [119].

\subsection{Glucomannan-Flavor Compounds Interactions}

Konjac glucomannan is a linear polysaccharide consisting of mannose units linked by $\beta(1 \rightarrow 4)$ bonds and glucosyl residues which are acetylated 5 to $10 \%$. It has the ability to form highly viscous solutions at low concentrations, and the presence of acetyl groups in the chain inhibits the formation of intramolecular hydrogen bonds, which improves its solubility [120]. Further, it creates interactions synergistically with starch, carrageenan, xanthan and gellan gum, and due to its high water holding capacity, it prevents syneresis in starch gels and reduces the retrogradation degree of starch [18]. The effect of konjac glucomannan (combined with and without potato starch) on flavor compounds was examined in a study by Lafarge et al. [18] using three flavor compounds (ethyl acetate, ethyl hexanoate and carvacrol). In the retention of ethyl hexanoate, there was no difference between the three different dispersions used (potato starch, konjac glucomannan and potato starch-konjac glucomannan combination), which indicated that there was no specific interaction of this component with the tested polysaccharides. Ethyl acetate had over $50 \%$ lower retention in the konjac glucomannan dispersion (compared to the other two), and a possible reason for this was the lower concentration of polysaccharides in that dispersion. The addition of konjac glucomannan to the potato starch dispersion reduced carvacrol retention, i.e., reduced the amylose-flavor interaction due to the inhibition of starch granule swelling. 
The retention of flavor compounds from different chemical groups onto polysaccharides is different for each group. In a study by Bylaite et al. [121], it was observed that the addition of $\lambda$-carrageenan had an effect on the release of flavor compounds from the $\lambda$-carrageenan-thickened solution. Although the release rate decreased for all flavor compounds, differences were observed between different chemical groups so that esters had the highest decrease in the release rate, followed by aldehydes, ketones and alcohols, respectively. The explanation for the most pronounced decreased release rate of esters could be that decrease in flavor compounds diffusion rate occurred through macromolecule entanglement due to weak interactions between the $\lambda$-carrageenan chains and esters. In contrast, other studies have shown that alcohols were usually best retained onto polysaccharides due to the formation of glycosidic bonds. The sorption of propanol and 1-hexanol onto $\beta$-cyclodextrin was higher than the sorption of ethyl acetate and diacetyl [122]. Further, alcohols retention was best in high amylose starch following by acids and aldehydes [3].

\section{Conclusions}

Polysaccharides and flavor are components present in food products, and their interactions may affect product quality. Flavor compounds are highly valuable bioactive substances, which need to be preserved from losses. It is therefore necessary to enable their controlled release in food products. For this purpose, encapsulation of flavor compounds is applied, the efficiency of which is influenced by various factors. When applying one of the encapsulation techniques, it is essential, among other things, to have a detailed understanding of the nature of the coating and coated materials. Interactions that take place during this process, but also subsequently, will affect the stability, i.e., retention and release of the trapped compound. According to published studies, these interactions take place mainly through non-covalent interactions, but also an inclusion complex can be formed. Although numerous studies have been conducted on this topic, understanding and clarification of these interactions continue to be a work in progress, with a need for further research and improvement.

Author Contributions: Conceptualization, M.K., A.P. and J.Š.; investigation, I.B., I.I.; writingoriginal draft preparation, I.B.; writing - review and editing, M.K., A.P. and J.Šs.; supervision, M.K. and A.P.; project administration, M.K.; funding acquisition, M.K. All authors have read and agreed to the published version of the manuscript.

Funding: This work was part of the projects PZS-2019-02-1595 (supported by the "Research Cooperability" Program of the Croatian Science Foundation funded by the European Union from the European Social Fund under the Operational Programme Efficient Human Resources 2014-2020) and IP-2019-04-5749 (financed by the Croatian Science Foundation).

Institutional Review Board Statement: Not applicable.

Informed Consent Statement: Not applicable.

Data Availability Statement: Not applicable.

Conflicts of Interest: The authors declare no conflict of interest.

\section{References}

1. Tromelin, A.; Merabtine, Y.; Andriot, I. Retention-release equilibrium of aroma compounds in polysaccharide gels: Study by quantitative structure-activity/property relationships approach. Flavour Fragr. J. 2010, 25, 431-442. [CrossRef]

2. Landy, P.; Courthaudon, J.L.; Dubois, C.; Voilley, A. Effect of interface in model food emulsions on the volatility of aroma compounds. J. Agric. Food Chem. 1996, 44, 526-530. [CrossRef]

3. Naknean, P.; Meenune, M. Factors affecting retention and release of flavour compounds in food carbohydrates. Int. Food Res. J. 2010, 17, 23-34.

4. Zhang, Y.; Zhou, Y.; Cao, S.; Li, S.; Jin, S.; Zhang, S. Preparation, release and physicochemical characterisation of ethyl butyrate and hexanal inclusion complexes with $\beta$ - and $\gamma$-cyclodextrin. J. Microencapsul. 2015, 32, 711-718. [CrossRef] [PubMed]

5. Paravisini, L.; Guichard, E. Interactions between aroma compounds and food matrix. In Flavour: From Food to Perception; Guichard, E., Salles, C., Morzel, M., Le Bon, A., Eds.; Whiley: Hoboken, NJ, USA, 2016; pp. 208-234. 
6. Lukić, I.; Radeka, S.; Grozaj, N.; Staver, M.; Peršurić, Đ. Changes in physico-chemical and volatile aroma compound composition of Gewürztraminer wine as a result of late and ice harvest. Food Chem. 2016, 196, 1048-1057. [CrossRef] [PubMed]

7. Xiao, Q.; Zhou, X.; Xiao, Z.; Niu, Y. Characterization of the differences in the aroma of cherry wines from different price segments using gas chromatography-mass spectrometry, odor activity values, sensory analysis, and aroma reconstitution. Food Sci. Biotechnol. 2017, 26, 331-338. [CrossRef]

8. Du, X.F.; Kurnianta, A.; McDaniel, M.; Finn, C.E.; Qian, M.C. Flavour profiling of "Marion" and thornless blackberries by instrumental and sensory analysis. Food Chem. 2010, 121, 1080-1088. [CrossRef]

9. Qian, M.C.; Wang, Y. Seasonal variation of volatile composition and odor activity value of "Marion" (Rubus spp. hyb) and “Thornless Evergreen” (R. laciniatus L.) blackberries. J. Food Sci. 2005, 70, C13-C20. [CrossRef]

10. Gao, Q.; Zhang, B.; Qiu, L.; Fu, X.; Huang, Q. Ordered structure of starch inclusion complex with C10 aroma molecules. Food Hydrocoll. 2020, 108, 105969. [CrossRef]

11. Winska, K.; Maczka, W.; Lyczko, J.; Grabarczyk, M.; Czubaszek, A.; Szumny, A. Essential oils as antimicrobial Agents-Myth or real alternative? Molecules 2019, 24, 2130. [CrossRef]

12. Cuccovia, I.M.; Schroeter, E.H.; Monteiro, P.M.; Chaimovich, H. Effect of hexadecyltrimethylammonium bromide on the thiolysis of p-nitrophenyl acetate. J. Org. Chem. 1978, 43, 2248-2252. [CrossRef]

13. Arias, M.; García-Falcón, M.S.; García-Río, L.; Mejuto, J.C.; Rial-Otero, R.; Simal-Gándara, J. Binding constants of oxytetracycline to animal feed divalent cations. J. Food Eng. 2007, 78, 69-73. [CrossRef]

14. Astray, G.; Mejuto, J.C.; Morales, J.; Rial-Otero, R.; Simal-Gándara, J. Factors controlling flavors binding constants to cyclodextrins and their applications in foods. Food Res. Int. 2010, 43, 1212-1218. [CrossRef]

15. Burgess, D.J.; Ponsart, S. $\beta$-Glucuronidase activity following complex coacervation and spray drying microencapsulation. J. Microencapsul. 1998, 15, 569-579. [CrossRef] [PubMed]

16. Madene, A.; Jacquot, M.; Scher, J.; Desobry, S. Flavour encapsulation and controlled release-A review. Int. J. Food Sci. Technol. 2006, 41, 1-21. [CrossRef]

17. Arvisenet, G.; Le Bail, P.; Voilley, A.; Cayot, N. Influence of physicochemical interactions between amylose and aroma compounds on the retention of aroma in food-like matrices. J. Agric. Food Chem. 2002, 50, 7088-7093. [CrossRef]

18. Lafarge, C.; Cayot, N.; Hory, C.; Goncalves, L.; Chassemont, C.; Le Bail, P. Effect of konjac glucomannan addition on aroma release in gels containing potato starch. Food Res. Int. 2014, 64, 412-419. [CrossRef]

19. Cardador-Martínez, A.; Espino-Sevilla, M.T.; Martín del Campo, S.T.; Alonzo-Macías, M. Dietary fiber as food additive: Present and future. In Dietary Fiber Functionality in Food and Nutraceuticals: From Plant to Gut, 1st ed.; Hosseinian, F., Oomah, B.D., Campos-Vega, R., Eds.; Wiley: Chichester, UK, 2016; pp. 77-94.

20. Li, Q.; Liu, R.; Wu, T.; Zhang, M. Aggregation and rheological behavior of soluble dietary fibers from wheat bran. Food Res. Int. 2017, 102, 291-302. [CrossRef]

21. Jakobek, L.; Matić, P. Non-covalent dietary fiber-Polyphenol interactions and their influence on polyphenol bioaccessibility. Trends Food Sci. Technol. 2018, 83, 235-247. [CrossRef]

22. Quirós-Sauceda, A.E.; Palafox-Carlos, H.; Sáyago-Ayerdi, S.G.; Ayala-Zavala, J.F.; Bello-Perez, L.A.; Álvarez-Parrilla, E.; de la Rosa, L.A.; Gonzáles-Córdova, A.F.; González-Aguilar, G.A. Dietary fiber and phenolic compunds as functional ingredients: Interaction and possible effect after ingestion. Food Funct. 2014, 5, 1063-1072. [CrossRef] [PubMed]

23. Fietz, V.R.; Salgado, J.M. Pectin and cellulose effects on cholesterol serum levels, and triglycerides in hiperlipidemic rats. Food Sci. Technol. 1999, 19, 318-321. [CrossRef]

24. Bernaud, F.S.R.; Rodrigues, T.C. Fibra alimentar: Ingestão adequada e efeitos sobre a saúde do metabolismo. Arq. Bras. Endocrinol. Metab. 2013, 57, 397-405. [CrossRef]

25. Dos Santos Costa, T.; Rogez, H.; da Silva Pena, R. Adsorption capacity of phenolic compounds onto cellulose and xylan. Food Sci. Technol. 2015, 35, 314-320. [CrossRef]

26. Voilley, A.; Souchon, I. Flavour retention and release from the food matrix: An overview. In Flavour in Food, 1st ed.; Voilley, A., Etiévant, P., Eds.; Elsevier: Amsterdam, The Netherlands, 2006; pp. 117-132.

27. Guichard, E. Interactions between flavor compounds and food ingredients and their influence on flavor perception. Food Rev. Int. 2002, 18, 49-70. [CrossRef]

28. Reineccius, G.A. Carbohydrates for flavor encapsulation. Food Technol. 1991, 45, 144-147.

29. Tari, T.A.; Singhal, R.S. Starch based spherical aggregates: Reconfirmation of the role of amylose on the stability of a model flavouring compound, vanillin. Carbohydr. Polym. 2002, 50, 279-282. [CrossRef]

30. Saifullah, M.; Islam Shishir, M.R.; Ferdowsi, R.; Tanver Rahman, M.R.; Van Vuong, Q. Micro and nano encapsulation, retention and controlled release of flavor and aroma compounds: A critical review. Trends Food Sci. Technol. 2019, 86, 230-251. [CrossRef]

31. Fang, Z.; Bhandari, B. Encapsulation of polyphenols-A review. Trends Food Sci. Technol. 2010, 21, 510-523. [CrossRef]

32. Goubet, I.; Dahout, C.; Sémon, E.; Guichard, E.; Le Quéré, J.L.; Voilley, A. Competitive binding of aroma compounds by $\beta$-cyclodextrin. J. Agric. Food Chem. 2001, 49, 5916-5922. [CrossRef]

33. Vukoja, J.; Pichler, A.; Ivić, I.; Šimunović, J.; Kopjar, M. Cellulose as a delivery system of raspberry juice volatiles and their stability. Molecules 2020, 25, 2624. [CrossRef]

34. Sillick, M.; Gregson, C.M. Spray chill encapsulation of flavors within anhydrous erythritol crystals. LWT Food Sci. Technol. 2012, 48, 107-113. [CrossRef] 
35. Sosa, N.; Schebor, C.; Pérez, O.E. Encapsulation of citral in formulations containing sucrose or trehalose: Emulsions properties and stability. Food Bioprod. Process. 2014, 92, 266-274. [CrossRef]

36. Tampau, A.; González-Martinez, C.; Chiralt, A. Carvacrol encapsulation in starch or PCL based matrices by electrospinning. J. Food Eng. 2017, 214, 245-256. [CrossRef]

37. Koupantsis, T.; Pavlidou, E.; Paraskevopoulou, A. Glycerol and tannic acid as applied in the preparation of milk proteins-CMC complex coavervates for flavour encapsulation. Food Hydrocoll. 2016, 57, 62-71. [CrossRef]

38. Laokuldilok, N.; Thakeow, P.; Kopermsub, P.; Utama-ang, N. Optimisation of microencapsulation of turmeric extract for masking flavour. Food Chem. 2016, 194, 695-704. [CrossRef]

39. Sanchez-Reinoso, Z.; Osorio, C.; Herrera, A. Effect of microencapsulation by spray drying on cocoa aroma compounds and physicochemical characterisation of microencapsulates. Powder Technol. 2017, 318, 110-119. [CrossRef]

40. Sultana, A.; Miyamoto, A.; Lan Hy, Q.; Tanaka, Y.; Fushimi, Y.; Yoshii, H. Microencapsulation of flavors by spray drying using Saccharomyces cerevisiae. J. Food Eng. 2017, 199, 36-41. [CrossRef]

41. Shishir, M.R.I.; Chen, W. Trends of spray drying: A critical review on drying of fruit and vegetable juices. Trends Food Sci. Technol. 2017, 65, 49-67. [CrossRef]

42. Escher, F.E.; Nuessli, J.; Conde-Petit, B. Interactions of flavor compounds with starch in food processing. In Flavor Release, 1st ed.; Roberts, D., Taylor, A., Eds.; American Chemical Society: Washington, DC, USA, 2000; pp. 230-245.

43. Vidrih, R.; Zlatić, E.; Hribar, J. Release of strawberry aroma compounds by different starch-aroma systems. Czech J. Food Sci. 2009, 27 (Suppl. S1), S58-S61. [CrossRef]

44. Jouquand, C.; Ducruet, V.; Le Bail, P. Formation of amylose complexes with C6-aroma compounds in starch dispersions and its impact on retention. Food Chem. 2006, 96, 461-470. [CrossRef]

45. Tapanapunnitkul, O.; Caiseri, S.; Peterson, D.G.; Thompson, D.B. Water solubility of flavor compounds influences formation of flavor inclusion complexes from dispersed high-amylose maize starch. J. Agric. Food Chem. 2008, 56, 220-226. [CrossRef] [PubMed]

46. Tietz, M.; Buettner, A.; Conde-Petit, B. Interaction between starch and aroma compounds as measured by proton transfer reaction mass spectrometry (PTR-MS). Food Chem. 2008, 108, 1192-1199. [CrossRef]

47. Van Ruth, S.M.; King, C. Effect of starch and amylopectin concentrations on volatile flavour release from aqueous model food systems. Flavour Fragr. J. 2003, 18, 407-416. [CrossRef]

48. Eliasson, A.C. Interactions between starch and lipids studied by DSC. Thermochim. Acta 1994, 246, 343-356. [CrossRef]

49. Obiro, W.C.; Ray, S.S.; Emmambux, M.N. V-amylose structural characteristics, methods of preparation, significance, and potential applications. Food Rev. Int. 2012, 28, 412-438. [CrossRef]

50. Boutboul, A.; Giampaoli, P.; Feigenbaum, A.; Ducruet, V. Use of inverse gas chromatography with humidity control of the carrier gas to characterise aroma-starch interactions. Food Chem. 2000, 71, 387-392. [CrossRef]

51. Boutboul, A.; Giampaoli, P.; Feigenbaum, A.; Ducruet, V. Influence of the nature and treatment of starch on aroma retention. Carbohydr. Polym. 2002, 47, 73-82. [CrossRef]

52. Chattopadhyaya, S. Oxidised starch as gum arabic substitute for encapsulation of flavours. Carbohydr. Polym. 1998, 37, 143-144. [CrossRef]

53. Qiu, C.; Chang, R.; Yang, J.; Ge, S.; Xiong, L.; Zhao, M.; Sun, Q. Preparation and characterization of essential oil-loaded starch nanoparticles formed by short glucan chains. Food Chem. 2017, 221, 1426-1433. [CrossRef]

54. Sun, P.; Zeng, M.; He, Z.; Qin, F.; Chen, J. Controlled release of fluidized bed-coated menthol powder with a gelatin coating. Dry. Technol. 2013, 31, 1619-1626. [CrossRef]

55. Bortnowska, G.; Goluch, Z. Retention and release kinetics of aroma compounds from white sauces made with native waxy maize and potato starches: Effects of storage time and composition. Food Hydrocoll. 2018, 85, 51-60. [CrossRef]

56. Ades, H.; Kesselman, E.; Ungar, Y.; Shimoni, E. Complexation with starch for encapsulation and controlled release of menthone and menthol. LWT Food Sci. Technol. 2012, 45, 277-288. [CrossRef]

57. Shi, L.; Hopfer, H.; Ziegler, G.R.; Kong, L. Starch-menthol inclusion complex: Structure and release kinetics. Food Hydrocoll. 2019, 97, 105183-105190. [CrossRef]

58. Savary, G.; Lafarge, C.; Doublier, J.L.; Cayot, N. Distribution of aroma in a starch-polysaccharide composite gel. Food Res. Int. 2007, 40, 709-716. [CrossRef]

59. Zhang, S.; Zhou, Y.; Jin, S.; Meng, X.; Yang, L.; Wang, H. Preparation and structural characterization of corn starch-aroma compound inclusion complexes. J. Sci. Food Agric. 2016, 97, 182-190. [CrossRef] [PubMed]

60. Fernandes, R.V.D.B.; Borges, S.V.; Botrel, D.A. Gum arabic/starch/maltodextrin/inulin as wall materials on the microencapsulation of rosemary essential oil. Carbohydr. Polym. 2014, 101, 524-532. [CrossRef] [PubMed]

61. Sanchez, V.; Baeza, R.; Galmarini, M.V.; Zamora, M.C.; Chirife, J. Freeze-drying encapsulation of red wine polyphenols in an amorphous matrix of maltodextrin. Food Bioproc. Technol. 2011, 6, 1350-1354. [CrossRef]

62. Jouquand, C.; Ducruet, V.; Giampaoli, P. Partition coefficients of aroma compounds in polysaccharide solutions by the phase ratio variation method. Food Chem. 2004, 85, 467-474. [CrossRef]

63. Mao, L.; Roos, Y.H.; Miao, S. Effect of maltodextrins on the stability and release of volatile compounds of oil-in-water emulsions subjected to freeze-thaw treatment. Food Hydrocoll. 2015, 50, 219-227. [CrossRef] 
64. Siccama, J.W.; Pegiou, E.; Zhang, L.; Mumm, R.; Hall, R.D.; Boom, R.M.; Schutyser, M.A.I. Maltodextrin improves physical properties and volatile compound retention of spray-dried asparagus concentrate. LWT Food Sci. Technol. 2021, 142, 111058-111069. [CrossRef]

65. Faridi Esfanjani, A.; Jafari, S.M.; Assadpour, E. Preparation of a multiple emulsion based on pectin-whey protein complex for encapsulation of saffron extract nanodroplets. Food Chem. 2017, 221, 1962-1969. [CrossRef]

66. Rajabi, H.; Ghorbani, M.; Jafari, S.M.; Sadeghi Mahoonak, A.; Rajabzadeh, G. Retention of saffron bioactive components by spray drying encapsulation using maltodextrin, gum Arabic and gelatin as wall materials. Food Hydrocoll. 2015, 51, 327-337. [CrossRef]

67. Tackenberg, M.W.; Krauss, R.; Schuchmann, H.P.; Kleinebudde, P. Encapsulation of orange terpenes investigating a plasticisation extrusion process. J. Microencapsul. 2015, 32, 408-417. [CrossRef] [PubMed]

68. Tackenberg, M.W.; Marmann, A.; Thommes, M.; Schuchmann, H.P.; Kleinebudde, P. Orange terpenes, carvacrol and $\alpha$-tocopherol encapsulated in maltodextrin and sucrose matrices via batch mixing. J. Food Eng. 2014, 135, 44-52. [CrossRef]

69. Farouk, A.; El-Kalyoubi, M.; Ali, H.; Mageed, M.A.E.; Khallaf, M.; Moawad, A. Effects of carriers on spray-dried flavors and their functional characteristics. Pak. J. Biol. Sci. 2020, 23, 257-263. [CrossRef]

70. Galmarini, M.V.; Zamora, M.C.; Baby, R.; Chirife, J.; Mesina, V. Aromatic profiles of spray-dried encapsulated orange flavours: Influence of matrix composition on the aroma retention evaluated by sensory analysis and electronic nose techniques. Int. J. Food Sci. Technol. 2008, 43, 1569-1576. [CrossRef]

71. Vincken, J.P.; Schols, H.A.; Visser, R.G. If homogalacturonan were a side chain of rhamnogalacturonan I. Implications for cell wall architecture. Plant Physiol. 2003, 132, 1781-1789. [CrossRef] [PubMed]

72. Dobson, C.C.; Mottawea, W.; Rodrigue, A.; Buzati Pereira, L.B.; Hammami, R.; Power, A.K.; Bordenave, N. Impact of molecular interactions with phenolic compounds on food polysaccharides functionality. In Advances in Food and Nutrition Research, 1st ed.; Ferreira, I.C.F.R., Barros, L., Eds.; Academic Press: Cambridge, MA, USA, 2019; Volume 90, pp. 135-181.

73. Mesbahi, G.; Jamalian, J.; Farahnaky, A. A comparative study on functional properties of beet and citrus pectins in food systems. Food Hydrocoll. 2005, 19, 731-738. [CrossRef]

74. Munarin, F.; Tanzi, M.C.; Petrini, P. Advances in biomedical applications of pectin gels. Int. J. Biol. Macromol. 2012, 51, 681-689. [CrossRef]

75. Mamet, T.; Yao, F.; Li, K.; Li, C. Persimmon tannins enhance the gel properties of high and low methoxyl pectin. LWT Food Sci. Technol. 2017, 86, 594-602. [CrossRef]

76. Preininger, M. Interactions of flavor components in Foods. In Ingredient Interactions: Effects on Food Quality, 2nd ed.; Gaonkar, A.G., McPherson, A., Eds.; CRC Press: Boca Raton, FL, USA, 2005; pp. 477-542.

77. Guichard, E.; Issanchou, S.; Descourvieres, A.; Etievant, P. Pectin concentration, molecular weight and degree of esterification: Influence on volatile composition and sensory characteristics of strawberry Jam. J. Food Sci. 1991, 56, 1621-1627. [CrossRef]

78. Braudo, E.E.; Plashchina, I.G.; Kobak, V.V.; Golovnya, R.V.; Zhuravleva, I.L.; Krikunova, N.I. Interactions of flavor compounds with pectic substances. Food/Nahrung 2000, 44, 173-177. [CrossRef]

79. Szejtli, J. Introduction and general overview of cyclodextrin chemistry. Chem. Rev. 1998, 98, 1743-1754. [CrossRef] [PubMed]

80. Szente, L.; Szejtli, J. Cyclodextrins as food ingredients. Trends Food Sci. Technol. 2004, 15, 137-142. [CrossRef]

81. Connors, K.A. The stability of cyclodextrin complexes in solution. Chem. Rev. 1997, 97, 1325-1358. [CrossRef]

82. Sanemasa, I.; Wu, Y.; Koide, Y.; Fujii, T.; Takahashi, H.; Deguchi, T. Stability on drying of cyclodextrin precipitates of volatile nonelectrolytes. Bull. Chem. Soc. Jpn. 1994, 67, 2744-2750. [CrossRef]

83. Tobitsuka, K.; Miura, M.; Kobayashi, S. Interaction of cyclodextrins with aliphatic acetate esters and aroma components of La France pear. J. Agric. Food Chem. 2005, 53, 5402-5406. [CrossRef]

84. Yang, X.; Yang, F.; Liu, Y.; Li, J.; Song, H. Off-flavor removal from thermal-treated watermelon juice by adsorbent treatment with $\beta$-cyclodextrin, xanthan gum, carboxymethyl cellulose sodium, and sugar/acid. LWT Food Sci. Technol. 2020, 131, 109775-409784. [CrossRef]

85. Riviş, A.; Hădărugă, N.G.; Hadăruga, D.I.; Trasca, T.; Druga, M.; Pinzaru, I. Bioactive nanoparticles: The complexation of odorant compounds with $\alpha$-and $\beta$-cyclodextrin. Rev. Chim. 2008, 59, 149-153. [CrossRef]

86. Ponce Cevallos, P.A.; Buera, M.P.; Elizalde, B.E. Encapsulation of cinnamon and thyme essential oils components (cinnamaldehyde and thymol) in $\beta$-cyclodextrin: Effect of interactions with water on complex stability. J. Food Eng. 2010, 99, 70-75. [CrossRef]

87. Tao, F.; Hill, L.E.; Peng, Y.; Gomes, C.L. Synthesis and characterization of $\beta$-cyclodextrin inclusion complexes of thymol and thyme oil for antimicrobial delivery applications. LWT Food Sci. Technol. 2014, 59, 247-255. [CrossRef]

88. Dos Santos, C.; Buera, M.P.; Mazzobre, M.F. Influence of ligand structure and water interactions on the physical properties of $\beta$-cyclodextrins complexes. Food Chem. 2012, 132, 2030-2036. [CrossRef]

89. Dos Santos, C.; del Pilar Buera, M.; Mazzobre, M.F. Phase solubility studies of terpineol with $\beta$-cyclodextrins and stability of the freeze-dried inclusion complex. Procedia Food Sci. 2011, 1, 355-362. [CrossRef]

90. Numanoğlu, U.; Şen, T.; Tarimci, N.; Kartal, M.; Koo, O.M.Y.; Önyüksel, H. Use of cyclodextrins as a cosmetic delivery system for fragrance materials: Linalool and benzyl acetate. AAPS PharmSciTech 2007, 8, 34-42. [CrossRef] [PubMed]

91. Ceborska, M.; Szwed, K.; Suwinska, K. $\beta$-Cyclodextrin as the suitable molecular container for isopulegol enantiomers. Carbohydr. Polym. 2013, 97, 546-550. [CrossRef] [PubMed]

92. Nuchuchua, O.; Saesoo, S.; Sramala, I.; Puttipipatkhachorn, S.; Soottitantawat, A.; Ruktanonchai, U. Physicochemical investigation and molecular modeling of cyclodextrin complexation mechanism with eugenol. Food Res. Int. 2009, 42, 1178-1185. [CrossRef] 
93. Hill, L.E.; Gomes, C.; Taylor, T.M. Characterization of beta-cyclodextrin inclusion complexes containing essential oils (transcinnamaldehyde, eugenol, cinnamon bark, and clove bud extracts) for antimicrobial delivery applications. LWT Food Sci. Technol. 2013, 51, 86-93. [CrossRef]

94. Yuan, C.; Lu, Z.; Jin, Z. Characterization of an inclusion complex of ethyl benzoate with hydroxypropyl- $\beta$-cyclodextrin. Food Chem. 2014, 152, 140-145. [CrossRef]

95. Kfoury, M.; Auezova, L.; Ruellan, S.; Greige-Gerges, H.; Fourmentin, S. Complexation of estragole as pure compound and as main component of basil and tarragon essential oils with cyclodextrins. Carbohydr. Polym. 2015, 118, 156-164. [CrossRef]

96. Songkro, S.; Hayook, N.; Jaisawang, J.; Maneenuan, D.; Chuchome, T.; Kaewnopparat, N. Investigation of inclusion complexes of citronella oil, citronellal and citronellol with $\beta$-cyclodextrin for mosquito repellent. J. Incl. Phenom. Macrocycl. Chem. 2012, 72, 339-355. [CrossRef]

97. Reineccius, T.A.; Reineccius, G.A.; Peppard, T.L. Flavor release from cyclodextrin complexes: Comparison of alpha, beta, and gamma types. J. Food Sci. 2003, 68, 1234-1239. [CrossRef]

98. Kayaci, F.; Sen, H.S.; Durgun, E.; Uyar, T. Functional electrospun polymeric nanofibers incorporating geraniol-cyclodextrin inclusion complexes: High thermal stability and enhanced durability of geraniol. Food Res. Int. 2014, 62, 424-431. [CrossRef]

99. Zhu, G.; Xiao, Z.; Zhou, R.; Zhu, Y. Study of production and pyrolysis characteristics of sweet orange flavor- $\beta$-cyclodextrin inclusion complex. Carbohydr. Polym. 2014, 105, 75-80. [CrossRef] [PubMed]

100. Roberts, D.D.; Elmore, J.S.; Langley, K.R.; Bakker, J. Effects of sucrose, guar gum, and carboxymethylcellulose on the release of volatile flavor compounds under dynamic conditions. J. Agric. Food Chem. 1996, 44, 1321-1326. [CrossRef]

101. Jouquand, C.; Aguni, Y.; Malhiac, C.; Grisel, M. Influence of chemical composition of polysaccharides on aroma retention. Food Hydrocoll. 2008, 22, 1097-1104. [CrossRef]

102. Kenyon, M.M. Modified starch, maltodextrin, and corn syrup solids as wall materials for food encapsulation. In Encapsulation and Controlled Release of Food Ingredients; Risch, S.J., Reineccius, G.A., Eds.; American Chemical Society: Washington, DC, USA, 1995; Volume 590, pp. 42-50.

103. Shiga, H.; Yoshii, H.; Nishiyama, T.; Furuta, T.; Forssele, P.; Poutanen, K.; Linko, P. Flavor encapsulation and release characteristics of spray-dried powder by the blended encapsulant of cyclodextrin and gum arabic. Dry. Technol. 2001, 19, 1385-1395. [CrossRef]

104. Kuck, L.S.; Noreña, C.P.Z. Microencapsulation of grape (Vitis labrusca var. Bordo) skin phenolic extract using gum Arabic, polydextrose, and partially hydrolyzed guar gum as encapsulating agents. Food Chem. 2016, 194, 569-576. [CrossRef]

105. Apintanapong, M.; Noomhorm, A. The use of spray drying to microencapsulate 2-acetyl-1-pyrroline, a major flavour component of aromatic rice. Int. J. Food Sci. Technol. 2003, 38, 95-102. [CrossRef]

106. Terta, M.; Blekas, G.; Paraskevopoulou, A. Retention of selected aroma compounds by polysaccharide solutions: A thermodynamic and kinetic approach. Food Hydrocoll. 2006, 20, 863-871. [CrossRef]

107. Savary, G.; Hucher, N.; Bernadi, E.; Grisel, M.; Malhiac, C. Relationship between the emulsifying properties of Acacia gums and the retention and diffusion of aroma compounds. Food Hydrocoll. 2010, 24, 178-183. [CrossRef]

108. Savary, G.; Hucher, N.; Petibon, O.; Grisel, M. Study of interactions between aroma compounds and acacia gum using headspace measurements. Food Hydrocoll. 2014, 37, 1-6. [CrossRef]

109. Yang, Z.Y.; Fan, Y.G.; Xu, M.; Ren, J.N.; Liu, Y.L.; Zhang, L.L.; Fan, G. Effects of xanthan and sugar on the release of aroma compounds in model solution. Flavour Fragr. J. 2016, 32, 112-118. [CrossRef]

110. Yven, C.; Guichard, E.; Giboreau, A.; Roberts, D.D. Assessment of interactions between hydrocolloids and flavor compounds by sensory, headspace, and binding methodologies. J. Agric. Food Chem. 1998, 46, 1510-1514. [CrossRef]

111. Guichard, E.; Etiévant, P. Measurement of interactions between polysaccharides and flavor compounds by exclusion size chromatography: Advantages and limits. Food/Nahrung 1998, 42, 376-379. [CrossRef]

112. Kopjar, M.; Ivić, I.; Vukoja, J.; Šimunović, J.; Pichler, A. Retention of linalool and eugenol in hydrogels. Int. J. Food Sci. Technol. 2019, 55, 1416-1425. [CrossRef]

113. Bylaite, E.; Adler-Nissen, J.; Meyer, A.S. Effect of xanthan on flavor release from thickened viscous food model systems. J. Agric. Food Chem. 2005, 53, 3577-3583. [CrossRef] [PubMed]

114. Gössinger, M.; Buchmayer, S.; Greil, A.; Griesbacher, S.; Kainz, E.; Ledinegg, M.; Leitner, M.; Mantler, A.C.; Hanz, K.; Bauer, R.; et al. Effect of xanthan gum on typicity and flavour intensity of cloudy apple juice. J. Food Process. Preserv. 2018, 42, 13737-13742. [CrossRef]

115. Ma, M.; Tan, L.; Dai, Y.; Zhou, J. An investigation of flavor encapsulation comprising of regenerated cellulose as core and carboxymethyl cellulose as wall. Iran. Polym. J. 2013, 22, 689-695. [CrossRef]

116. Sansukcharearnpon, A.; Wanichwecharungruang, S.; Leepipatpaiboon, N.; Kerdcharoen, T.; Arayachukeat, S. High loading fragrance encapsulation based on a polymer-blend: Preparation and release behavior. Int. J. Pharm. 2010, 391, 267-273. [CrossRef]

117. Kondo, T. Nematic ordered cellulose: Its structure and properties. In Cellulose: Molecular and Structural Biology; Brown, R.M., Saxena, I.M., Eds.; Springer: Dordrecht, The Netherlands, 2007; pp. 285-305.

118. Zhu, F.; Du, B.; Xu, B. A critical review on production and industrial applications of beta-glucans. Food Hydrocoll. 2016, 52, 275-288. [CrossRef]

119. Christensen, N.J.; Trindade Leitão, S.M.; Petersen, M.A.; Jespersen, B.M.; Engelsen, S.B. A Quantitative structure-property relationship study of the release of some esters and alcohols from barley and oat $\beta$-glucan matrices. J. Agric. Food Chem. 2009, 57, 4924-4930. [CrossRef] 
120. Lafarge, C.; Cayot, N. Potential use of mixed gels from konjac glucomannan and native starch for encapsulation and delivery of aroma compounds: A review. Starch-Starke 2017, 70, 1700159. [CrossRef]

121. Bylaite, E.; Ilgūnaite, Ž.; Meyer, A.S.; Adler-Nissen, J. Influence of $\lambda$-carrageenan on the release of systematic series of volatile flavor compounds from viscous food model systems. J. Agric. Food Chem. 2004, 52, 3542-3549. [CrossRef]

122. Le Thanh, M.; Thibeaudeau, P.; Thibaut, M.A.; Voilley, A. Interactions between volatile and non-volatile compounds in the presence of water. Food Chem. 1992, 43, 129-135. [CrossRef] 